Aksaray University
Journal of Science and Engineering
e-ISSN: 2587-1277
http://dergipark.gov.tr/asujse
http://asujse.aksaray.edu.tr

Research Article

\title{
Hydrogeochemical, Geotechnical and Soil Geochemistry Characteristics of Aksaray University Campus Area, Aksaray
}

\author{
Gökhan Demirela*, Erkan Yilmazer, Mustafa Murat Kavurmaci \\ Department of Geological Engineering, Faculty of Engineering, Aksaray University, Aksaray 68100, Turkey \\ -Received Date: Apr 01, $2020 \quad$ •Revised Date: May 13, $2020 \quad$ Accepted Date: May 15, $2020 \quad$-Published Online: Jun 26, 2020
}

\begin{abstract}
This study aims to investigate hydrogeological, geochemical and geotechnical properties of the Aksaray University campus area. Within this context, the hydrogeochemical results of water samples collected from 4 different water points from the campus area, geochemical analysis of 17 soil samples, and geotechnical properties of rock samples obtained from drill core and description of core-logging performed in 2008 were evaluated. Hydrogeological studies have shown that two different water facies with $\mathrm{Na}-\mathrm{Cl}$ and $\mathrm{Ca}-\mathrm{Cl}$ water types developed in the study area. These waters are classified as low quality, but usable, and $3^{\text {rd }}$ quality for irrigation water according to irrigation water standards and electrical conductivity values. According to geotechnical experiments, it was determined that the argillaceous limestone, which spread widely under the cover of the campus area, had bearing capacity of $36.5 \mathrm{~kg} / \mathrm{cm}^{2}$ and belonged to the low strength rock class. As and $\mathrm{Pb}$ contents of the soil samples are at higher values, compared to the average upper crust values. According to the anomaly distribution maps prepared for $\mathrm{Cl}$ and $\mathrm{Na}$ elements, it was determined that east, southwest and northwest parts of the campus area contain higher values of $\mathrm{Na}$ and $\mathrm{Cl}$ than that of other parts of campus. The results of this study will provide more planned and efficient green-area studies to be carried out in the campus area and protection of the green-areas.
\end{abstract}

\section{Keywords}

Aksaray University, Geotechnics, Hydrogeology, Geochemistry, Soil contamination

"Corresponding Author: Gökhan Demirela, gdemirela@aksaray.edu.tr 


Aksaray University
Journal of Science and Engineering
e-ISSN: 2587-1277
http://dergipark.gov.tr/asujse
http://asujse.aksaray.edu.tr

Research Article

\title{
Aksaray Üniversitesi Kampüs Alanının Hidrojeokimyasal, Jeoteknik ve Toprak Jeokimyası Karakteristikleri, Aksaray
}

\author{
Gökhan Demirela ${ }^{\dagger}$, Erkan Yılmazer, Mustafa Murat Kavurmacı
}

Aksaray Üniversitesi Mühendislik Fakültesi Jeoloji Mühendisliği Bölümü, Aksaray 68100, Türkiye

-Gönderi Tarihi: 01 Nis $2020 \quad$-Düzeltme Tarihi: 13 May $2020 \quad$ •Kabul Tarihi: 15 May 2020 $\quad$ •Çevrimiçi Yayın Tarihi: 24 Haz 2020

\section{Özet}

Bu çalışma, Aksaray Üniversitesi kampüs alanının, hidrojeolojik, jeokimyasal ve jeoteknik bakımdan incelenmesini konu almaktadır. Bu kapsam doğrultusunda, kampüs alanı içerisinden 4 farklı su noktasından toplanan su örneklerine ait analiz sonuçları, 17 adet toprak numunesinin jeokimyasal analizi ve 2008 yılında gerçekleştirilen sondajlardan elde edilen kuyu logtanımlamaları ile kaya numunelere ait jeoteknik özellikler incelenmiştir. Hidrojeolojik çalışmalar, inceleme alanında $\mathrm{Na}-\mathrm{Cl}$ ve $\mathrm{Ca}-\mathrm{Cl}$ su tiplerine sahip iki farklı su fasiyesinin geliştiğini göstermiştir. $\mathrm{Bu}$ sular, sulama suyu standartlarına ve elektriksel iletkenlik değerlerine göre sulama suyu kalitesi düşük ancak kullanılabilir III. kalite sulama suyu olarak sınıflandırılmıştır. Jeoteknik incelemelere göre, kampüs alanı örtü tabakasının altında geniş yayılım gösteren killi kireçtaşlarının güvenli taşıma gücü değerinin $36,5 \mathrm{~kg} / \mathrm{cm}^{2}$ olduğu ve mukavemeti düşük dayanımlı kayaç sınıfına girdiği belirlenmiştir. Toprak örneklerinin As ve $\mathrm{Pb}$ içerikleri, ortalama üst kabuk değerlerine göre yüksek sayılabilecek değerlerdedir. $\mathrm{Cl}$ ve $\mathrm{Na}$ elementleri için hazırlanan anomali dağılım haritalarına göre, kampüs alanının doğu, güney batı ve kuzey batı kesimlerinin $\mathrm{Na}$ ve $\mathrm{Cl}$ elementleri bakımından diğer bölgelere oranla daha yüksek değerler içerdiği belirlenmiştir. $\mathrm{Bu}$ çalışmanın sonuçları, kampüs alanı içerisinde gerçekleştirilecek yeşil alan çalışmalarının daha planlı ve verimli bir şekilde yapılabilmesine olanak tanıyacak ve yeşil alanların geliştirilmesine katkı sağlayacaktır.

\section{Anahtar kelimeler}

Aksaray Üniversitesi, Jeoteknik, Hidrojeoloji, Jeokimya, Toprak kirliliği

†'Sorumlu Yazar: Gökhan Demirela, gdemirela@aksaray.edu.tr 


\section{GIRIŞ̧}

Günümüzde, hızlı nüfus artışına ve sanayileşmeye paralel olarak her geçen gün su kaynaklarına duyulan ihtiyaç artmaktadır. Özellikle kurak ve yarı kurak iklim kuşağında yer alan ülkemizde, temiz su kaynaklarının noktasal veya alansal kirleticilerin etkisi ile kirlenerek, su kalitelerinin önemli ölçüde azalması veya tamamen kullanım özelliklerini yitirmesi, ekolojik dengeyi etkileyen en önemli sorunların başında gelmektedir. Sanayileşme, çarpık ve plansız kentleşme, yanlış yer seçimi, bilimsel metod ve denetimden uzak tarımsal sulama faaliyetleri hem su kaynaklarının hem de toprakların kalitelerinin bozulmasına neden olabilmektedir.

Canlıların ve hayatın en temel gereksinimi olan su, hidrolojik çevrim sayesinde sürekli yenilenen doğal bir kaynaktır. Kökeni ve kaynağı ne olursa olsun sulama suları etkileşimde oldukları kayaç ve topraklardan çözmüş oldukları bir takım element ve mineralleri bünyelerine almakta olup, bir sulama suyunun kalitesi ise bu konsept dahilinde içinde çözünmüş halde bulunan iyon ve maddelerin toplam konsantrasyonu ile belirlenmektedir [1] . Daha da önemlisi mevcut su kaynaklarımızın korunması ve sürdürülebilir devamlılığının sağlanabilmesi için su kalitesinin sürekli izlenmesini gerektirmektedir.

$\mathrm{Su}$ ve toprak kalitesine etki eden en önemli faktörlerden birisi de ağır metallerdir. Su ve topraklarda $\mathrm{Cr}, \mathrm{Ni}, \mathrm{Fe}, \mathrm{Mn}, \mathrm{Co}, \mathrm{Cu}, \mathrm{Zn}, \mathrm{Mo}, \mathrm{Pb}, \mathrm{As}, \mathrm{Hg}, \mathrm{Ag}$ vb. elementler için ekolojik anlamda ağır metal terimi kullanılsa da gerçekte atom numarası 20'den büyük elementler ağır metaller olarak sınıflanmaktadır [2-3]. Bu metallerden bazıları (örneğin $\mathrm{Cr}$, $\mathrm{Ni}, \mathrm{Co}, \mathrm{Cu}, \mathrm{Fe}, \mathrm{Mn}$, Mo) her ne kadar toksik olsa da hayvan ve bitkiler için belirli oranlarda gerekli iken, bazıları da (örneğin $\mathrm{Pb}, \mathrm{As}, \mathrm{Hg}, \mathrm{Ag}$ ) tamamen toksik ve zararlıdır [3]. Bu metaller belirli alanlarda (çoğunlukla metalik maden yatakları ve civarlarında) doğal yollardan zenginleşebileceği gibi, nüfus, tarım ve sanayi alanlarının yoğunlaştığı yerleşim bölgeleri ve civarlarında insan faaliyetlerine dayalı olarak toprak, su ve havada her geçen gün giderek daha fazla zenginleşmektedir [4-6]. Bu metaller, jeolojik işlemler sonucunda toprak ve sularda dolayısıyla da bu alanlarda yaşayan bitki, hayvan ve insan bünyelerinde limit değerler üzerinde zenginleşebilir. Böylece zaman içerisinde döngülenerek hem toprak-su hem de besin zincirinin kirlenmesine ve bozulmasina neden olurlar [3, 6-9].

Yerleşim alanlarındaki yeşil alanların korunması ve geliştirilmesine önemli katkılar sağlayan zirai sulama faaliyetlerinin sağlıklı bir şekilde yürütülmesi, bu alanların sulanmasında kullanılan su kaynaklarının hidrojeokimyasal özelliklerinin kesin olarak belirlenmesi ile mümkün olabilmektedir. Özellikle sulama sonucu toprak kimyası ve yapısında meydana gelen 
değişimlerin de su kalitesi ile birlikte değerlendirilmesi ve sistematik olarak incelenmesi ekonomik ve zamansal kayıpların önlenmesi bakımından son derece önemli gözükmektedir.

2006 yılında kurulan Aksaray Üniversitesi (ASÜ) Merkez kampüs alanı yaklaşık 11 km² 'lik bir alan üzerine kurulmuştur. Kampüs alanı içinde rektörlük, 12 fakülte, 3 enstitü, 2 yüksekokul, 16 uygulama ve araştırma merkezi, 2 sosyal tesis, 1 merkezi konferans salonu, 1 yarı olimpik yüzme havuzu, 1 kapalı spor tesisi, 1 stadyum (7500 kişilik), 2 tenis kortu, 1 mediko, 1 çarşı ve 2 öğrenci yurdu bulunmakta olup 1300'ün üzerinde yabancı uyruklu (başta Türkmenistan, Azerbaycan, Suriye, Irak ve Afganistan gibi 49 ayrı ülkeden) olmak üzere 22000'e yakın öğrenciye ev sahipliği yapmaktadır. ASÜ'nün mevcut en önemli sorunlarından birisi içinde bulunmuş olduğu jeolojik ve iklim koşullarına bağlı olarak su kaynakları ve toprak kimyasından kaynaklanan yeşil alan oluşturma güçlüğüdür. Kurulduğu günden itibaren ağaçlandırma ve yeşil alan oluşturma çalışmaları sırasında özellikle ağaçlarda köklerde kuruma, yapraklarda sararma gibi problemler ile ağaç gelişiminin zayıf kaldığı gözlenmektedir. Kampüs alanına dikilen fidanların yaklaşık \%70'nin yeterince gelişemediği ve dikim itibari ile 2 sene içerisinde tamamen kuruduğu dikkati çekmektedir. Bu doğrultuda, üniversite yönetimi kampüs dişından toprak getirme yoluna gitmekte, “Acil Toprak Aranıyor” gibi sosyal sorumluluk projeleri ile var olan problemli bölgeleri rehabilite etmeye çalışmaktadır.

ASÜ’nün söz konusu bu büyük probleminin tespiti ve çözümüne yönelik olarak 2018 yılında 4 farklı su noktasından su örnekleri alınarak su kalitesinin belirlenmesi ve sınıflanması amacı ile su kimyası analizleri gerçekleştirilmiştir. Su analizlerinin yanı sıra toprağın kimyası ve yapısının karakteristiklerinin saptanabilmesi için 17 farklı toprak örneği analiz edilmiş bunun yanı sıra 2008 yılında gerçekleştirilen sondaj faaliyetlerinden elde edilen kuyu logları, sondaj karot determinasyonları ile kaya numunelere ait jeoteknik özellikler incelenmiştir. Ayrıca kampüs alanına çok yakın bir mevkide Linde Gaz A.Ş. tarafından $\mathrm{CO}_{2}$ gazı aramaları ve üretimi amacı ile açılmış bir adet sondaj kuyusuna dair kuyu logları ve hidrojeokimyasal veriler yeniden değerlendirilmiştir.

Yapılan çalışmalar kapsamında elde edilen hidrojeolojik, jeokimyasal ve jeoteknik veriler bir bütün halinde değerlendirilmiş ve sonuç olarak kampüs alanı içerisinde tarımsal olarak görece daha uyun bölgeler tespit edilmiştir. Bu bölgelerin uygunluk dereceleri ve dağılımları ile risk oluşturabilecek jeolojik sebepler belirlenmeye çalışılmıştır. Bu sayede, kampüs alanı içerisinde daha verimli yeşil alan geliştirme çalışmaları yapılabilecek ve su yönetim planlaması daha doğru ve başarılı bir şekilde uygulanması sağlanacaktır. 


\section{MATERYAL ve METOT}

\section{1. Örnekleme ve Analizler}

Araştırma kapsamında çalışma alanı içerisinde Mayıs 2018 tarihinde 4 adet sulama amaçlı açılan kuyudan su örnekleri ve 17 adet farklı lokasyondan ise toprak örnekleri derlenmiştir. 40 cm derinlikde ideal B toprak zonuna karşılık gelecek şekilde alınan örneklerin ana oksit ve iz element içeriklerinin belirlenmesi amacı ile toprak örneklemesi yapılmıştır. Su örnekleri asitsiz olarak çift kapaklı 1 litrelik polietilen şişelere alınmıştır. Su örnekleri üzerinde fiziksel ve kimyasal su kalite analizleri Aksaray Üniversitesi Çevre Mühendisliği Bölümü Su Kimyası Laboratuvarı'nda, toprak örneklerinin jeokimyasal analizleri ise Aksaray Üniversitesi Bilimsel ve Teknolojik Uygulama ve Araştırma Merkezi'nde WD-XRF cihazı ile gerçekleştirilmiştir. Aynı zamanda çalışma alanının zemin ve kaya özelliklerinin belirlenebilmesi için, 2008 yılında açılan 6 farklı araştırma sondajından elde edilen karot numunelerin jeoteknik verileri de bu çalışma kapsamında kullanılmıştır. Killi kireçtaşından yapılan araştırma sondajı çalışmaları neticesinde elde edilen $61 \mathrm{~mm}$ çapındaki muhtelif numune karotları üzerinde bir dizi kaya mekaniği deneyleri Kadıköy Belediyesi, Çevre Koruma ve Kontrol Müdürlüğü Zemin-Beton Laboratuarları'nda yapılmıştır.

Su kimyası analizlerinden elde edilen veriler uygun veri tabanı formatında düzenlendikten sonra AquaChem programı kullanılarak hidrojeokimysal açıdan değerlendirilmiş ayrıca toprak numunelerine ait verilerin anomali dağılım haritalarının üretilmesinde ArcGIS gibi Coğrafi Bilgi Sistemi (CBS) yazılımları kullanılmıştır. Haritalarının oluşturulmasında kriging interpolasyon yöntemi tercih edilmiştir.

\section{JEOLOJI}

\section{1. Çalışma Alanının Tanıtımı}

İnceleme alanı, Türkiye'de İç Anadolu Bölgesi'nde 330 58' ve 340 04' doğu boylamları ile 380 19,84' ve 380 19,01' kuzey enlemleri arasında L31 b3 ve L32 a4 paftaları içerisinde yer alır (Şekil 1). Kampüs alanı Orta Anadolu'nun yaklaşık kuzeyi ile güneyini, doğusu ile batısını birleştiren karayollarının kesişme bölgesindedir. Batısında Aksaray ilini Adana iline bağlayan E-90 Karayolu, güneyinde Aksaray Oganize Sanayi Bölgesi ve Hasandağı, kuzey ve doğusunda ise Aksaray il merkezi yer almaktadır. İnceleme alanı düz bir topoğrafyaya sahiptir. İnceleme alanı içerisinde suni drenaj kanalları dışında önemli bir akarsu ağı bulunmaz. İnceleme alanının ortalama denizden yüksekliği 955 m kampüs alanı içerisinde kapladığı alan ise yaklaşık 5 km² dir. Bölgenin ortalama yıllık sıcaklığg $12,4{ }^{0} \mathrm{C}$, ortalama yıllık yağış miktarı ise 360 mm'dir. 


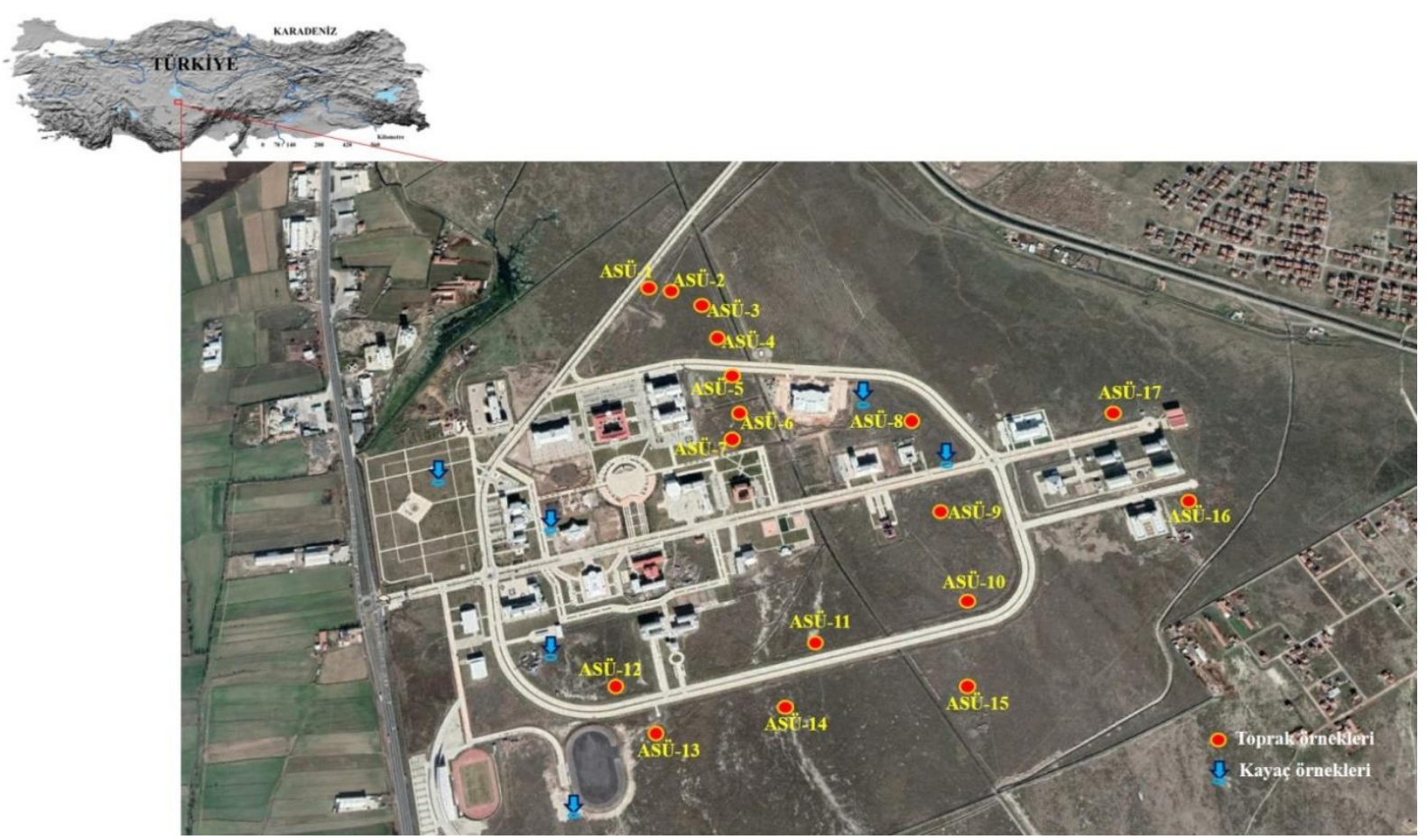

Şekil 1. Aksaray Üniversitesi Kampüs alanı ve saha çalışmaları sırasında gerçekleştirilen toprak ve kayaç örnek noktalarını gösterir yer bulduru haritası.

\subsection{Genel Jeoloji}

Çalışma alanının temelinde Orta Anadolu Kristalen Kompleksi'ne ait kayaç birimleri yer alır [10-11] . Bu kompleks düzenli bir istif sunan Orta Anadolu Metamorfitleri, Orta Anadolu Ofiyolitleri ile bu birimleri sicak dokanakla kesen Orta Anadolu Granitoyitleri’nden meydana gelen kaya türleri ile temsil edilir [12]. Tuz Gölü Havzası bu temel üzerine Geç Kretase Oligosen zaman aralığında gelişen bir havzadır. Gerilmeli rejime bağlı olarak gelişen sübsidans Geç Kretase - Orta Eosen süresince meydana gelmiş ve bunu Geç Eosen'den Oligosen sonlarına kadar devam eden sıkışmalı rejim havzayı etkilemiştir [13-14]. Anadolu bloğunun batıya kaçmasıyla Geç Miyosen - Erken Pliyosen'de fay kontrollü iç havzalar gelişmiştir [14 ] Tuz Gölü Havzası Geç Kretase'den başlayıp Orta Eosen sonuna kadar denizel ve Geç Eosen Kuvaterner zaman aralığında karasal nitelikli sedimanter birimlerle doldurulmuş bir havzadır [13-15]. Sedimanter istifin kompozit kalınlığı bölgede yaklaşık $2500 \mathrm{~m}$ civarındadır [12] . Bölgedeki en önemli yapısal unsurlar Tuz Gölü ve Sultanhanı fay zonlarıdır. Bu faylar KB-GD gidişli birbirlerine paralel normal bileşeni olan doğrultu atımlı fay sistemleri ile karakterize olurlar [14]. Bu ana fayları farklı açılarla kesen KD-GB gidişli düşey bileşenli fay sistemleri de bulunur.

\section{3. İnceleme Alanının Jeolojisi}

İnceleme alanı içinde 2008 yılında toplam derinliği $90 \mathrm{~m}$, her biri yaklaşı 10 ile $20 \mathrm{~m}$ 
derinliğinde jeoteknik amaçlı 6 adet sondaj açılmıştır. Bunun yanında Linde Gaz A.Ş. tarafından $\mathrm{CO}_{2}$ üretimi ve tekrar yeraltına basma (re-enjeksiyon) için derinliği $300 \mathrm{~m}$ ile $700 \mathrm{~m}$ arasında kuyular açılmıştır. Sondaj verilerine göre, çalışma alanında alttan üstte doğru sırasıyla; 700 - 200 m arası kumtaşı - kil ardalanması, 200 - 30 m arasında siltli jipsli kil, 30 - 1 m arasında boşluklu killi kireçtaşı, 1 - 0 m arasında çoğunlukla siltli kum, az çakıllı kum ve siltli kil oluşan alüvyonlar yer almaktadır [16-17]. İncelenen karotlarda gözlenen kireçtaşları beyazımsı bej renkli olup, üst yüzeyleri yer yer kırıklı - çatlaklı, orta poroziteli, geçirgen özellikler gösterir. Birim kendi içerisinde ardalanmalı olarak zayıf zonlar içerir. Orta poroziteli kireçtaşının içerisinde boşluklar yer yer ikincil kalsit mineralleriyle doldurulmuştur (Şekil 2).

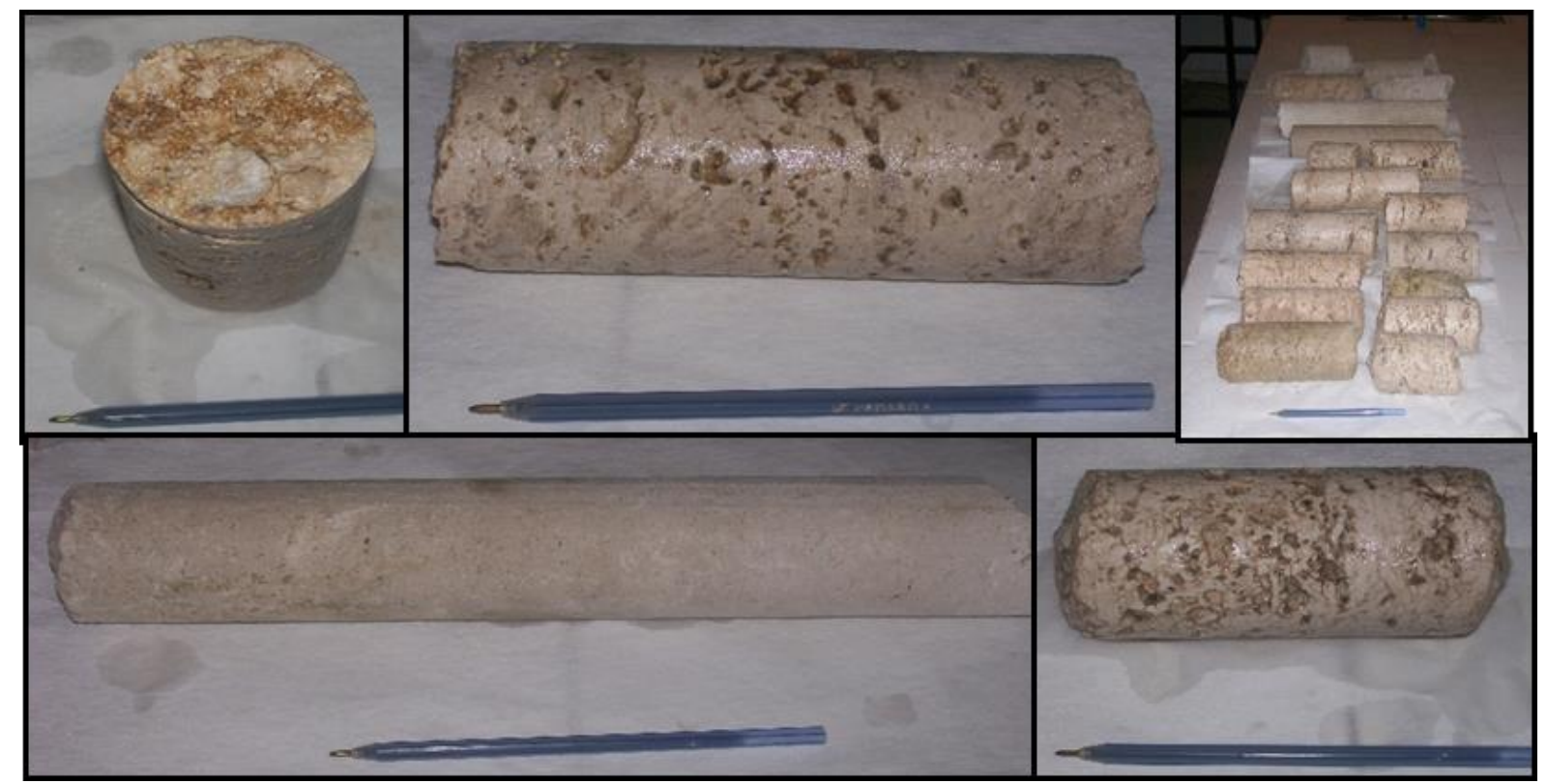

Şekil 2. Sondaj karotlarından alınan killi kireçtaşı örnekleri

Meteorik yağış sularının etkisiyle, mevsimsel değişimlere bağlı olarak yüksek ve düşük enerji kazanan akarsuların, sığ gölsel bir ortama materyal getirmeleri sonucu oluştuğu düşünülen birimin kendi içerisinde değişken yapı ve doku özellikleri gösterdiği de gözlenmiştir. Laboratuvar deney sonuçlarından elde edilen veriler doğrultusunda kil oranı yüksek kireçtaşının; düşük yoğunluğa sahip orta poroziteli ve zayıf dayanımlı bir kayaç olduğu belirlenmiştir.

Tüm birimleri uyumsuz olarak örten Kuvaterner yaşlı alüvyonlar; siltli kum, az çakıllı kum ve yüksek plastisiteli siltli kil seviyeleri şeklinde gözlenir. Özellikle üst kesimlerde killi seviyeler yoğundur. Killi seviyeler kahve renkli olup; pekişmiş-sıkılaşmış karakterde olup kumlu seviyeler ise gevşek yapıdadır. 1 - 0 m arasında gözlenen az çakıllı kumda çakılların kökenleri volkanik olup, yuvarlaklaşmıştır. 


\subsection{Hidrojeolojik Sistem}

İnceleme alanında yeraltı suyu taşıyan formasyonlar alüvyon ve erimeye bağlı ikincil porozite oranı yüksek zayıf zonlar içeren killi kireçtaşıdır. Alüvyon kalınlığı 1,5 - $5 \mathrm{~m}$ arasında değişmektedir. Yeraltı suyu seviyeleri 1,5 m ile $8 \mathrm{~m}$ arasında değişiklikler gösterebilmektedir. İnceleme alanında akifer oluşturan en önemli birim Tersiyer yaşlı kireçtaşı seviyeleridir. Kireçtaşları içerisinde düşey yönde gelişen çatlaklı, kırıklı ve karstik boşluklu kısımlar hidrojeolojik açıdan geçirimlidir. Kireçtaşı inceleme alanındaki sı̆̆ dolaşımlı düşük debili yeraltı suları için önemli bir akifer özelliğindedir. Birimin içerisindeki killi seviyeler geçirimliliği olumsuz yönde etkiler.

\section{BULGULAR ve TARTIŞMA}

\subsection{Hidrojeokimyasal Değerlendirme}

$\mathrm{Bu}$ bölümde, örnekleme noktalarından alınan su örneklerinin kimyasal analiz sonuçları ve arazide yerinde yapılan fizikokimyasal ölçümler hidrojeokimyasal açıdan değerlendirilmiştir. $\mathrm{Su}$ örnekleri üzerinde gerçekleştirilen kimyasal analiz çalışmalarına göre bazı fiziksel ve kimyasal parametrelerin değerleri; elektriksel iletkenlik: (EC) 1477 - $1703 \mu \mathrm{S} / \mathrm{cm}$, toplam çözünmüş katı madde miktarı (TDS): 1047 - 1170 mg/L, değişebilir sodium yüzdesi (\%Na): 31,3 - 41,3, sodium adsorbsiyon oran1 (SAR): 2,3 - 3,4 meq/L, alkalinite: 234 - $348 \mathrm{mg} / \mathrm{L}$ arasında değişmektedir (Tablo 1).

İnceleme alanında suların fiziksel ölçümleri mevsimsel değişmelere bağlı olarak çok az değişim göstermektedir. Ölçümlerde sistematik bir artış veya azalış belirlenememesi ve değerlerin birbirlerine yakın olması örneklerin genel olarak homojen bir dağılım gösterdiğini işaret etmektedir. EC değerlerinin tamamı, Su Kirliliği Kontrolü Yönetmeliği Teknik Usuller Tebliği tarafından belirlenen sulama suyu standartlarına göre III. kalite su sınıfı aralığında yer almıştır. EC değerlerine göre su örneklerinin tamamı sulama suyu kalitesi düşük ancak kullanılabilir sulama suyu olarak sınıflandırılmıştır. Aynı yönetmeliğe göre, sular \%Na değerleri açısından incelendiğinde Aks-2 ve Aks-3 numaralı örnekler II. kalite iyi su, Aks-1 ve Aks-4 numaralı sular ise III. kalite kullanılabilir su olarak tanımlanmıştır. Suların tamamı SAR değerleri açısından I. kalite su sınıfı olarak tanımlanabilir. Suların tamamı klorür değerleri açısından III. Kalite su olarak tanımlanırken, sülfat değerleri açısından I. kalite su olarak sınıflandırılabilir.

Hidrokimyasal açıdan Aks-1 ve Aks-4 numaralı sular Na-Cl, Aks-2 ve Aks-3 numaralı sular ise $\mathrm{Ca}-\mathrm{Cl}$ su fasiyesi özelliğindedir (Şekil 2). Söz konusu suların iyon bolluk dizilimleri genel olarak Aks-2 ve Aks-3 numaralı sular için $\mathrm{Ca}^{+2}>\left(\mathrm{Na}^{+}+\mathrm{K}^{+}\right)>\mathrm{Mg}^{+2} / \mathrm{Cl}^{-}>\mathrm{HCO}_{3}^{-}>\mathrm{SO}_{4}^{-2}, \mathrm{Aks}^{-}$ 
1 ve Aks-4 numaralı sular içinse $\left(\mathrm{Na}^{+}+\mathrm{K}^{+}\right)>\mathrm{Mg}^{+2}>\mathrm{Ca}^{+2} / \mathrm{Cl}^{-}>\mathrm{HCO}_{3}^{-}>\mathrm{SO}_{4}^{-2}$ şeklinde gelişmiştir. Suların anyon dizilimleri değişmezken katyon sıralamalarında $\mathrm{Ca}^{+2}$ iyonu konsantrasyonunun sistem içerisinde artıp azaldığı belirlenmiştir (Şekil 3).

Tablo 1. Su numunelerin hidrojeokimyasal özellikleri

\begin{tabular}{|c|c|c|c|c|}
\hline Fiziks el-Kimyasal par am etr eler & Aks-1 & Aks-2 & Aks-3 & Aks-4 \\
\hline Elektriksel iletken lik, $\mu \mathrm{S} / \mathrm{cm}$ & 1703 & 1477 & 1527 & 1682 \\
\hline Toplam çözünmüşs katı madde (mg/L) & 1170,2 & 1047,4 & 1060,2 & 1161,7 \\
\hline Değ işebilir Sodyum Yüzdes i (\% Na) & 41,1 & 35,7 & 31,3 & 41,3 \\
\hline Kalsiyum, mg Ca ${ }^{2+} / \mathrm{L}$ & 101,8 & 119,2 & 139,4 & 103,6 \\
\hline Magnezyum, $\mathrm{mg} \mathrm{Mg}^{2+} / \mathrm{L}$ & 67,07 & 49,02 & 52,73 & 66,72 \\
\hline Sodyum, $\mathrm{mg} \mathrm{Na}^{+} / \mathrm{L}$ & 177,2 & 133,1 & 123 & 179,2 \\
\hline Sodyum Adsorbsiy on oran1(SAR) meq/L & 3,3 & 2,6 & 2,3 & 3,4 \\
\hline Sodyum karbonat kalmtıs 1 (RSC) $\mathrm{mg} / \mathrm{L}$ & $-1,2$ & $-1,6$ & $-2,4$ & $-1,4$ \\
\hline Alkalinite, $\mathrm{mg} / \mathrm{L}$ & 348,6 & 292,4 & 234,1 & 299,5 \\
\hline Bikarbonat $\left(\mathrm{HCO}_{3}{ }^{-}\right)$ & 425,3 & 356,8 & 285,6 & 365,45 \\
\hline Klorür $\left(\mathrm{Cl}^{-}\right), \mathrm{mg} / \mathrm{L}$ & 344,6 & 314,21 & 398,25 & 401,54 \\
\hline Sülfat $\left(\mathrm{SO}_{4}{ }^{=}\right) \mathrm{mg} / \mathrm{L}$ & 54,25 & 75,12 & 61,24 & 45,25 \\
\hline Florür (F), mg/L & 1,025 & 0,756 & 0,456 & 0,548 \\
\hline $\mathrm{NO}_{3}{ }^{-} \mathrm{mg} / \mathrm{L}$ & 16,37 & 11,73 & 17,29 & 16,62 \\
\hline $\mathrm{NH}_{4}{ }^{+}, \mathrm{mg} / \mathrm{L}$ & 0 & 0,016 & 0,039 & 1,554 \\
\hline Bor kon s antrasy onu (mg/L) & 1,326 & 1,110 & 0,926 & 1,360 \\
\hline Alüminyum (Al), $\mu \mathrm{g} / \mathrm{L}$ & 42,03 & 10,99 & 7,193 & 2,355 \\
\hline $\operatorname{Arsenik}(\mathrm{As}), \mu \mathrm{g} / \mathrm{L}$ & 7,529 & 6,585 & 6,146 & 5,543 \\
\hline Berily um(Be), $\mu \mathrm{g} / \mathrm{L}$ & 15,67 & 15,72 & 15,77 & 15,82 \\
\hline Kadmiyum (Cd), $\mu \mathrm{g} / \mathrm{L}$ & 0 & 0 & 0 & 0 \\
\hline Krom $(\mathrm{Cr}), \mu \mathrm{g} / \mathrm{L}$ & 0 & 0 & 0 & 0 \\
\hline Kobalt $(\mathrm{Co}), \mu \mathrm{g} / \mathrm{L}$ & 0 & 0 & 0 & 0 \\
\hline Bakir $(\mathrm{Cu}), \mu \mathrm{g} / \mathrm{L}$ & 0,869 & 0 & 0 & 0 \\
\hline $\operatorname{Demir}(\mathrm{Fe}), \mu \mathrm{g} / \mathrm{L}$ & 5,887 & 0 & 0 & 0 \\
\hline Kurşun $(\mathrm{Pb}), \mu \mathrm{g} / \mathrm{L}$ & 0 & 0 & 0 & 0 \\
\hline Lityum (Li) $1, \mu \mathrm{g} / \mathrm{L}$ & 432,4 & 270,6 & 171,1 & 93,64 \\
\hline * Manganez $(\mathrm{Mn}), \mu \mathrm{g} / \mathrm{L}$ & 0 & 0 & 0 & 0 \\
\hline Molibden (Mo), $\mu \mathrm{g} / \mathrm{L}$ & 0 & 0 & 0 & 0 \\
\hline Nikel (Ni), $\mu \mathrm{g} / \mathrm{L}$ & 4,652 & 4,576 & 0 & 0 \\
\hline Selenyum (Se), $\mu \mathrm{g} / \mathrm{L}$ & 9,888 & 14,65 & 9,94 & 10,47 \\
\hline $\operatorname{Vanadyum}(\mathrm{V}), \mu \mathrm{g} / \mathrm{L}$ & 34,68 & 34,66 & 0 & 0 \\
\hline Çinko $(\mathrm{Zn}), \mu \mathrm{g} / \mathrm{L}$ & 0 & 0 & 0 & 0 \\
\hline Su lama suyu sinfi & $\mathrm{C}_{3} \mathrm{~S}_{1}$ & $\mathrm{C}_{3} \mathrm{~S}_{1}$ & $\mathrm{C}_{3} \mathrm{~S}_{1}$ & $\mathrm{C}_{3} \mathrm{~S}_{1}$ \\
\hline
\end{tabular}


Aks-1 ve Aks-4 numaralı sular diğer su örneklerine göre en düşük $\mathrm{Ca}^{+2}$ iyon derişimine sahipken yine bu sular diğer örneklere oranla en yüksek $\mathrm{HCO}_{3}{ }^{-}$iyon derişimine sahip oldukları gözlenmiştir (Şekil 3). $\mathrm{Ca}^{+2}$ ve $\mathrm{HCO}_{3}{ }^{-}$konsantrasyonlarının birbirlerine zıt eğilim göstermeleri iyon değişimlerine veya TDS değerlerinin de artması ile karakteristik olarak tuz içeren minerallerin çözünmesine [18] işaret etmektedir. İyon diziliminde gözlenen değişimin nedeni mevsimsel gelişen yağışlar, yeraltı sularının dolaşım süresinin uzaması veya suların zengin sodyum içeren kayaçlarla teması sonucu iyon değişimidir. Hidrolik sistemdeki farklı akiferlerin sularının birbirleriyle olan etkileşimi de zamansal iyon değişimini açıklayan diğer bir faktör olabilir. Bu sular bölgede karışım sularını temsil ederler. İyon bolluk dizilimleri bütün örnekleme dönemleri boyunca aynı kalmıştır. Tuz Gölü’nden uzaklaştıkça su kimyası fasiyesleri genel olarak $\mathrm{Na}-\mathrm{HCO}_{3}$ fasiyesinden $\mathrm{Ca}-\mathrm{HCO}_{3}$ fasiyesine dönüşür [19]. Yağışlı dönemde $\mathrm{Ca}^{+2}$ ve $\mathrm{HCO}_{3}{ }^{-}$iyonları daha fazla çözünmüş ve baskın konuma geçmişlerdir.
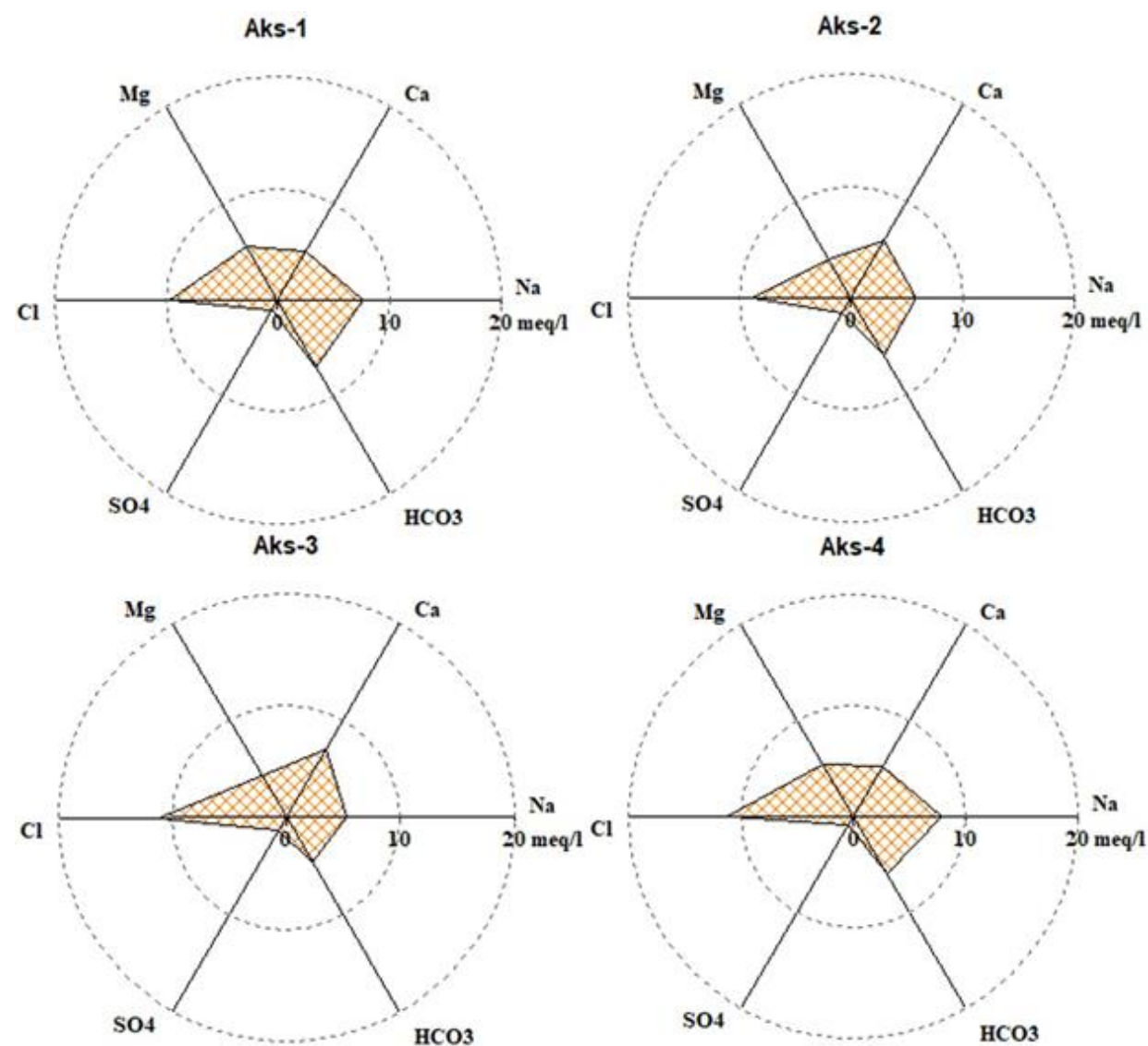

Şekil 3. Suların ana iyonlarının dağılımını karşılaştırmalı gösterir diyagram

İnceleme kapsamındaki su örneklerinin Piper üçgen diyagramdaki dağılımı incelendiğinde, suların tamamının diyagram üzerinde hiçbir iyonu \% 50'yi geçmeyen karışım sularını niteleyen 9. bölgede bulunduğu görülür (Şekil 4). Bu sular sodyum, kalsiyum, bikarbonatlı, klorürlü karışım sularıdır. 


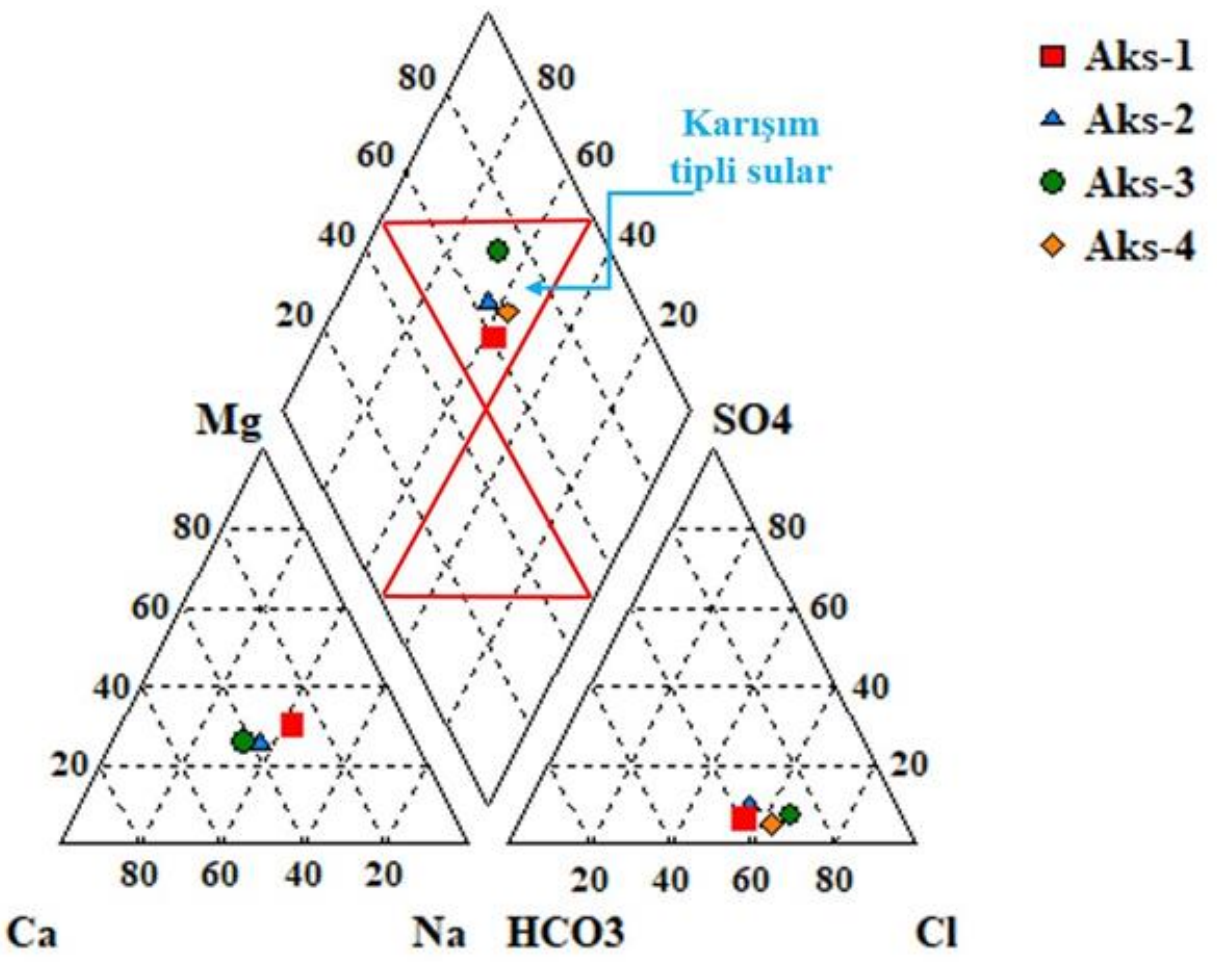

Şekil 4. Su örneklerine ait Piper üçgen diyagram

Suların Schoeller grafiğinde benzer dağılım göstermeleri bu suların tamamının benzer veya aynı akiferden geldiklerini gösterir (Şekil 5). Yeraltı sularının yüksek EC değerleri, $\mathrm{Na}^{+}$ve $\mathrm{Cl}^{-}$ içermeleri ve toplam mineralizasyon değerlerinin fazla olması bu suların derin ve uzun süreli dolaşım sistemine sahip sularla etkileşim halinde olduklarının bir göstergesi olarak önem arz etmektedir.

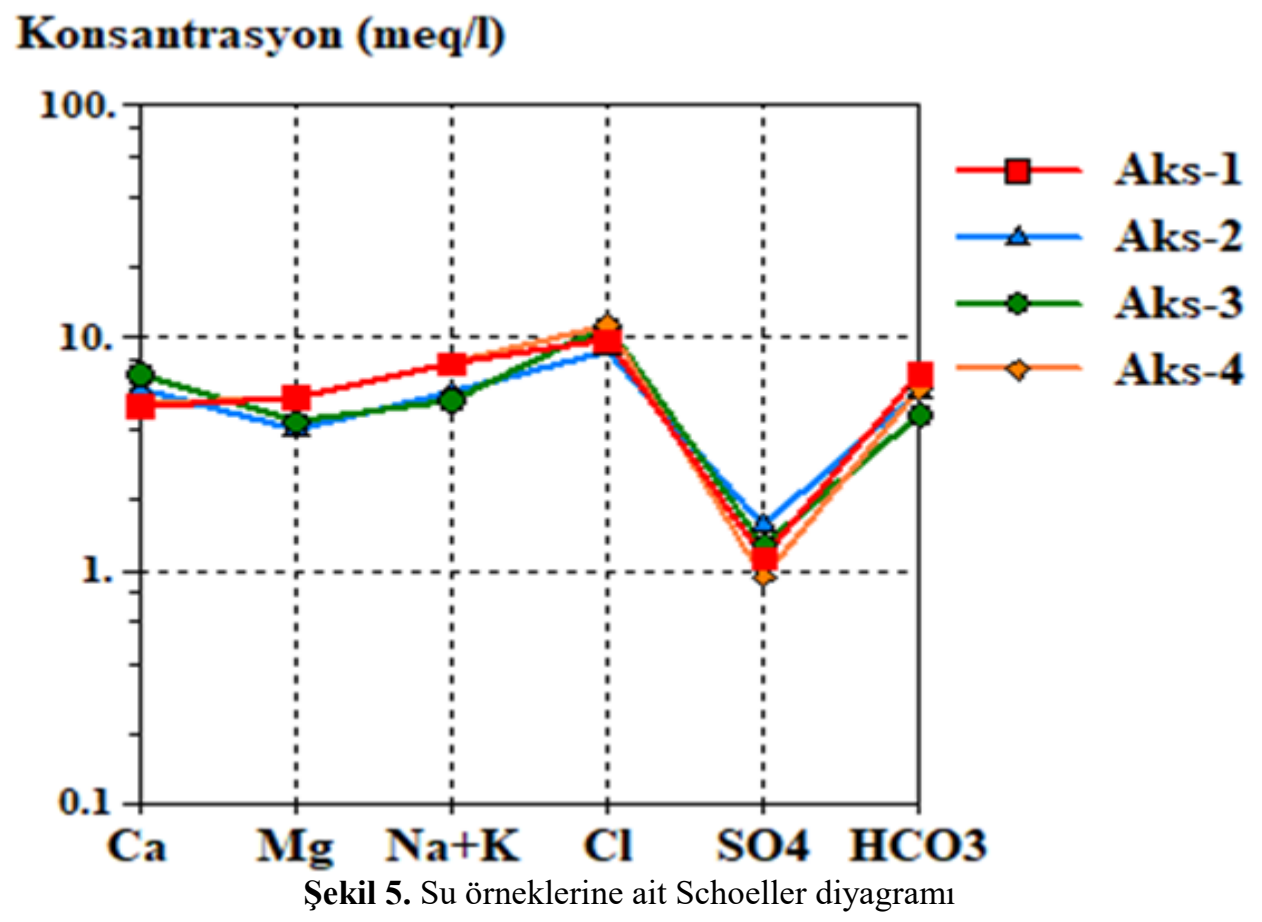


Örnekleme çalışmaları yapılan su kuyularının büyük çoğunluğu, inceleme alanında sulama suyu ihtiyacının karşılanması için kullanılmaktadır. Suların SAR ve elektriksel iletkenlik değerlerine göre sulama sularının sınıflandırılmasını sağlayan ABD tuzluluk laboratuvarı diyagramına göre sular iyi kullanılabilir sulama suları (C3S1) olarak sınıflandırılabilir.

\subsection{Kayaç Örneklerinin Jeoteknik Özellikleri}

İnceleme alanında killi kireçtaşından alınan karot numuneler üzerinde gerçekleştirilen üç eksenli sıkışma deney sonuçları değerlendirildiğinde bir numunenin kohezyonunun 3660 kpa, içsel sürtünme açısının ise 37,10 olduğu tespit edilmiştir (Tablo 2).

Tablo 2. Kireçtaşının üç eksenli sıkışma dayanımı deney sonuçları

\begin{tabular}{|c|c|c|c|}
\hline & $\mathbf{A}$ & $\mathbf{B}$ & $\mathrm{C}$ \\
\hline Boy (cm) & 10,8 & 10,8 & 10,8 \\
\hline Çap (cm) & 5 & 5,2 & 5 \\
\hline Kesit Alanı (cm²) & 19,63 & 21,23 & 19,63 \\
\hline Yanal Basınç (Mpa) & 3 & 6 & 9 \\
\hline Yenilme Yükü (kN) & 44,62 & 76,49 & 97,78 \\
\hline Eksenel Gerilim (Mpa) & 22,72 & 36,02 & 49,8 \\
\hline Kohezyon (c) & & $3660 \mathrm{kPa}$ & \\
\hline İçsel Sürtünme Açısı (૨) & & $37,1^{\circ}$ & \\
\hline
\end{tabular}

İnceleme alanında killi kireçtaşından alınan karot numuneler üzerinde laboratuvarda gerçekleştirilen tek eksenli basma dayanımı deney sonuçları ISRM'e [20] göre değerlendirildiğinde kireçtaşının mukavemetinin $\left(182,4 \mathrm{~kg} / \mathrm{cm}^{2}\right)$ düşük dayanımlı olduğu tespit edilmiştir (Tablo 3). Kaya numunelerine ait mühendislik özellikleri Tablo 3'de verilmiştir.

İnceleme alanının temelini teşkil eden killi kireçtaşı için 2 metre derinliğinde (Df), 2x2 metre boyutlarında (B) kare şeklinde bir temelin inşası için hesaplanan emniyet gerilmesi (qa); 18785 $\mathrm{kPa}=191,7 \mathrm{~kg} / \mathrm{cm}^{2}$ olarak hesaplanmıştır. Ancak zemin emniyet gerilmesi kayacın tek eksenli basma dayanımından $(17880 \mathrm{kPa})$ daha yüksek çıktığından nihai taşıma gücü olarak kayanın tek eksenli basma dayanımının alınması gerekmektedir. Burada da apartmanlar ve resmi binalar için güvenlik katsayısı (GK) 5 alınmıştır [21] . Bu sonuçlara göre güvenli taşıma gücü 36,5 $\mathrm{kg} / \mathrm{cm}^{2}$ olarak belirlenmiştir.

Laboratuvar deney sonuçlarından elde edilen veriler doğrultusunda, inceleme alanının temelini teşkil eden killi kireçtaşının, düşük yoğunluğa sahip, orta poroziteli ve zayıf dayanımlı bir kayaç olduğu tespit edilmiştir. 
Tablo 3. Kaya numunelerin mühendislik özellikleri

\begin{tabular}{|c|c|c|c|c|c|c|c|c|c|c|c|c|c|c|}
\hline $\begin{array}{l}\text { Örnek } \\
\text { No }\end{array}$ & $\begin{array}{c}\text { Numune } \\
\text { Şekli }\end{array}$ & $\begin{array}{l}\text { Boy } \\
\text { (cm) }\end{array}$ & $\begin{array}{l}\text { Çap } \\
(\mathrm{cm})\end{array}$ & $\begin{array}{c}\mathrm{V} \\
\left(\mathrm{cm}^{3}\right)\end{array}$ & $\begin{array}{r}\text { Sw } \\
(\mathrm{gr})\end{array}$ & $\begin{array}{l}\text { Swd } \\
\text { (gr) }\end{array}$ & $\begin{array}{l}\text { Ws } \\
(\%)\end{array}$ & $\begin{array}{c}\gamma_{k} \\
\left(\mathrm{gr} / \mathrm{cm}^{3}\right)\end{array}$ & $\begin{array}{c}\gamma d \\
\left(\mathrm{gr} / \mathrm{cm}^{3}\right)\end{array}$ & $\begin{array}{c}\mathrm{Vb} \\
\left(\mathrm{cm}^{3}\right)\end{array}$ & $\begin{array}{c}\mathbf{n} \\
(\%)\end{array}$ & e & $\begin{array}{c}\text { qu } \\
\text { (Mpa) }\end{array}$ & $\begin{array}{c}\mathrm{qu} \\
\left(\mathrm{kg} / \mathrm{cm}^{2}\right)\end{array}$ \\
\hline A1 & Karot & 13,3 & 6,13 & 392,3 & 858,5 & 904,5 & 5,36 & 2,19 & 2,31 & 46 & 11,73 & 0,13 & $\mathrm{~b}$ & $\mathrm{~b}$ \\
\hline A2 & Karot & 10,8 & 6,13 & 318,6 & 673 & 716,5 & 6,46 & 2,11 & 2,25 & 43,5 & 13,65 & 0,16 & 12,39 & 126,4 \\
\hline A3 & Karot & 13 & 6,13 & 383,5 & 688,5 & 767,5 & 11,47 & 1,8 & 2 & 79 & 20,6 & 0,26 & 6,36 & 64,9 \\
\hline A4 & Karot & 10,7 & 6,13 & 315,6 & 607,5 & 665,5 & 9,55 & 1,92 & 2,11 & 58 & 18,38 & 0,23 & 11,91 & 121,5 \\
\hline A5 & Karot & 12 & 6,13 & 354 & 645 & 719 & 11,47 & 1,82 & 2,03 & 74 & 20,91 & 0,26 & $\mathrm{~b}$ & $\mathrm{~b}$ \\
\hline A6 & Karot & 10,3 & 6,13 & 303,8 & 614,5 & 656 & 6,75 & 2,02 & 2,16 & 41,5 & 13,66 & 0,16 & 15,19 & 155 \\
\hline A7 & Karot & 12 & 6,13 & 354 & 799,5 & 829,5 & 3,75 & 2,26 & 2,34 & 30 & 8,48 & 0,09 & 33,19 & 338,5 \\
\hline A8 & Karot & 13 & 6,13 & 383,5 & 837,5 & 874,5 & 4,42 & 2,18 & 2,28 & 37 & 9,65 & 0,11 & 18,8 & 191,7 \\
\hline A9 & Karot & 12,2 & 6,13 & 359,9 & 798,5 & 830,5 & 4,01 & 2,22 & 2,31 & 32 & 8,89 & 0,1 & $\mathrm{~b}$ & $\mathrm{~b}$ \\
\hline A 10 & Karot & 11,5 & 6,13 & 339,2 & 693,5 & 737 & 6,27 & 2,04 & 2,17 & 43,5 & 12,82 & 0,15 & $\mathrm{~b}$ & $\mathrm{~b}$ \\
\hline A11 & Karot & 11 & 6,13 & 324,5 & 729,5 & 753,5 & 3,29 & 2,25 & 2,32 & 24 & 7,4 & 0,08 & 16,82 & 171,6 \\
\hline A12 & Karot & 11,3 & 6,13 & 333,3 & 778,5 & 792 & 1,73 & 2,34 & 2,38 & 13,5 & 4,05 & 0,04 & $\mathrm{~b}$ & $\mathrm{~b}$ \\
\hline A 13 & Karot & 10 & 6,13 & 295 & 645 & 669 & 3,72 & 2,19 & 2,27 & 24 & 8,14 & 0,09 & 21,7 & 221,4 \\
\hline A14 & Karot & 10,2 & 6,13 & 300,9 & 559,5 & 598,5 & 6,97 & 1,86 & 1,99 & 39 & 12,96 & 0,15 & $\mathrm{~b}$ & b \\
\hline A 15 & Karot & 12,6 & 6,13 & 371,7 & 880,5 & 895 & 1,65 & 2,37 & 2,41 & 14,5 & 3,9 & 0,04 & 21,62 & 220,5 \\
\hline A16 & Karot & 11,8 & 6,13 & 348,1 & 710,5 & 753,5 & 6,05 & 2,04 & 2,16 & 43 & 12,35 & 0,14 & b & b \\
\hline A17 & Karot & 11,2 & 6,13 & 330,4 & 789 & 825 & 4,56 & 2,39 & 2,5 & 36 & 10,9 & 0,12 & 20,86 & 212,8 \\
\hline
\end{tabular}

V: numune hacmi, Sw: kuru numune ağrllı̆ı, Swd; suy a doymuş numune ağrlı̆̆, Ws: ağrlıkça su emme, $\gamma_{k}$ : kuru birim hacim ağrlık,

$\gamma \mathrm{d}$ : yaş birim hacim ağrllk, $\mathrm{Vb}$ : boşluk hacmi, n:porozite, e: boşluk oranı, b:ölçüm değeri yok

\subsection{Toprak Jeokimyası}

Kampüs alanı içerisinden alınan 17 adet toprak numunesinin ana oksit içerikleri sırasıyla $\mathrm{SiO}_{2}$ $\%$ 14,21 ile 34,58, $\mathrm{TiO}_{2} \% 0,04$ ile 0,29, $\mathrm{Al}_{2} \mathrm{O}_{3} \%$ 0,51 ile 5,46, $\mathrm{Fe}_{2} \mathrm{O}_{3} \% 0,36$ ile 2,73, $\mathrm{MnO}$ $\% 0,02$ ile 0,06, $\mathrm{MgO} \% 7,69$ ile 24,84, $\mathrm{CaO} \% 11,74$ ile 35,46, $\mathrm{Na}_{2} \mathrm{O} \% 0,10$ ile 1,03, $\mathrm{K}_{2} \mathrm{O} \%$ 0,14 ile 0,67 ve $\mathrm{P}_{2} \mathrm{O}_{5}$ değerleri arasında değişmekte olup, ortalama \%19,89 $\mathrm{SiO} 2, \% 0,11 \mathrm{TiO}_{2}$, $\% 1,04 \mathrm{Al}_{2} \mathrm{O}_{3}, \% 1,04 \mathrm{Fe}_{2} \mathrm{O}_{3}, \% 0,04 \mathrm{MnO}, \% 15,46 \mathrm{MgO}, \%$ 19,61 CaO, \%0,41 $\mathrm{Na}_{2} \mathrm{O}, \% 0,32$ $\mathrm{K}_{2} \mathrm{O}, \%$ 0,10 $\mathrm{P}_{2} \mathrm{O}_{5}$ içermektedir (Tablo 4).

Ağır metal içerikleri açısından toprak numunelerinin $\mathrm{Cr}, \mathrm{Co}, \mathrm{Ni}, \mathrm{Cu}, \mathrm{Zn}, \mathrm{Pb}, \mathrm{Mo}$ ve $\mathrm{As}$ konsantrasyonları Tablo 5'de verilmiştir. Cr, 9,3 ile 29,5 ppm, Co, 4,6 ile 5,1 ppm, Ni, 4,4 ile 27 ppm, Cu, 0 ile 12,5 ppm, Zn, 8,6 ile 31,9 ppm, Pb, 28,5 1173,1 ppm, Mo, 2,7 ile 12,7 ppm, ve As, 13,9 ile 166,6 ppm arasında değişmekte olup ortalama 17,7 ppm Cr, Co 2,5 ppm, 15 ppm $\mathrm{Ni}, 5,8 \mathrm{Cu}, 16,4 \mathrm{Zn}, 533,6$ ppm Pb, 8,6 ppm Mo, 0,6 ppm Sb ve 77,4 ppm As içerdikleri tespit edilmişstir.

$\mathrm{Cr}, \mathrm{Co}, \mathrm{Ni}, \mathrm{Cu}$ ve $\mathrm{Zn}$, elementlerinin ölçüm değerleri, WHO (World Health Organization) ve FAO (Food and Agricultural Organization) [22] ile ÇŞB (Çevre ve Şehircilik Bakanlığı) [23] tarafından belirlenen standart sınır değerlerin altındadır. ASU_3 ve ASU_10 toprak örneklerinin Mo değerleri, Reinmann ve Caritat [24] tarafından önerilen sınır değerlerin çok az 
üzerinde ölçülmüş̧ür. $\mathrm{Pb}$ ve As değerleri ise WHO ve FAO belirlemiş olduğu sınır değerlerin çok üstündedir. Buna göre WHO, FAO, ÇŞB ve Reimann ve Caritat [24] tarafindan topraklardaki ağır metaller için tanımlanan eşik değer parametrelerine göre; inceleme alanı içerisinde $\mathrm{Pb}$ ve As elementlerince bir kirlilik söz konusu olduğu söylenebilir (Tablo 5; Şekil $6)$.

Tablo 4. Toprak numunelerin ana oksit (\%) analiz sonuçları

\begin{tabular}{|c|c|c|c|c|c|c|c|c|c|c|c|c|}
\hline Örnek No & $\mathrm{SiO}_{2}$ & $\mathrm{TiO}_{2}$ & $\mathrm{Al}_{2} \mathrm{O}_{3}$ & $\mathrm{Fe}_{2} \mathrm{O}_{3}$ & $\mathrm{MnO}$ & $\mathrm{MgO}$ & $\mathrm{CaO}$ & $\mathrm{Na}_{2} \mathrm{O}$ & $\mathrm{K}_{2} \mathrm{O}$ & $\mathrm{P}_{2} \mathrm{O5}$ & LOI & TOTAL \\
\hline$\overline{A S U ̈ \_1}$ & 20,47 & 0,10 & 1,69 & 0,88 & 0,04 & 13,37 & 21,05 & 0,13 & 0,23 & 0,10 & 43,97 & 102,02 \\
\hline ASÜ_2 & 18,96 & 0,08 & 1,17 & 0,75 & 0,04 & 13,67 & 22,25 & 0,50 & 0,21 & 0,12 & 45,17 & 102,93 \\
\hline ASÜ_3 & 19,06 & 0,21 & 2,08 & 2,29 & 0,06 & 11,88 & 19,15 & 0,26 & 0,52 & 0,12 & 41,24 & 96,87 \\
\hline ASÜ_4 & 15,11 & 0,10 & 0,92 & 0,98 & 0,04 & 15,21 & 19,94 & 0,03 & 0,22 & 0,09 & 46,32 & 98,97 \\
\hline ASÜ_5 & 17,16 & 0,15 & 1,48 & 1,37 & 0,05 & 11,38 & 19,01 & 0,16 & 0,46 & 0,10 & 45,35 & 96,66 \\
\hline ASÜ_6 & 17,43 & 0,12 & 1,29 & 1,16 & 0,04 & 13,71 & 24,27 & 0,14 & 0,26 & 0,11 & 41,39 & 99,92 \\
\hline $\mathrm{ASU}_{-7}^{-} 7$ & 22,96 & 0,08 & 0,93 & 0,74 & 0,03 & 16,46 & 20,79 & 0,15 & 0,22 & 0,10 & 39,38 & 101,83 \\
\hline ASÜ_8 & 16,95 & 0,06 & 0,64 & 0,54 & 0,03 & 24,84 & 11,74 & 0,10 & 0,14 & 0,10 & 45,30 & 100,43 \\
\hline ASÜ_9 & 14,78 & 0,06 & 0,66 & 0,54 & 0,03 & 20,89 & 19,51 & 0,27 & 0,24 & 0,09 & 43,37 & 100,45 \\
\hline ASÜ_10 & 16,33 & 0,07 & 0,67 & 0,61 & 0,03 & 19,86 & 16,90 & 0,24 & 0,27 & 0,07 & 41,92 & 96,98 \\
\hline ASÜ_11 & 18,37 & 0,15 & 1,32 & 1,56 & 0,05 & 18,33 & 15,47 & 0,77 & 0,48 & 0,12 & 37,31 & 93,92 \\
\hline ASÜ_12 & 19,68 & 0,10 & 0,94 & 1,00 & 0,04 & 13,85 & 19,04 & 1,03 & 0,47 & 0,09 & 41,97 & 98,21 \\
\hline ASÜ_13 & 14,21 & 0,05 & 0,65 & 0,45 & 0,02 & 8,42 & 35,46 & 0,05 & 0,15 & 0,06 & 42,47 & 102,01 \\
\hline ASÜ_14 & 19,86 & 0,14 & 1,42 & 1,39 & 0,04 & 20,55 & 15,44 & 0,92 & 0,52 & 0,12 & 37,69 & 98,09 \\
\hline ASÜ_- 15 & 26,10 & 0,04 & 0,51 & 0,36 & 0,03 & 17,15 & 16,13 & 0,17 & 0,14 & 0,08 & 39,18 & 99,87 \\
\hline ASÜ_16 & 26,09 & 0,04 & 0,65 & 0,38 & 0,03 & 15,48 & 18,95 & 1,90 & 0,29 & 0,19 & 39,30 & 103,29 \\
\hline ASÜ_17 & 34,58 & 0,29 & 5,46 & 2,73 & 0,06 & 7,69 & 18,27 & 0,24 & 0,67 & 0,09 & 32,04 & 102,10 \\
\hline minimum & 14,21 & 0,04 & 0,51 & 0,36 & 0,02 & 7,69 & 11,74 & 0,03 & 0,14 & 0,06 & 32,04 & 93,92 \\
\hline maksimum & 34,58 & 0,29 & 5,46 & 2,73 & 0,06 & 24,84 & 35,46 & 1,90 & 0,67 & 0,19 & 46,32 & 103,29 \\
\hline ortalama & 19,89 & 0,11 & 1,32 & 1,04 & 0,04 & 15,46 & 19,61 & 0,41 & 0,32 & 0,10 & 41,38 & 99,68 \\
\hline
\end{tabular}

Tablo 5. Toprak numunelerin $\mathrm{Cl}$ ve $\mathrm{Na}$ ile iz element (ppm) analiz sonuçları

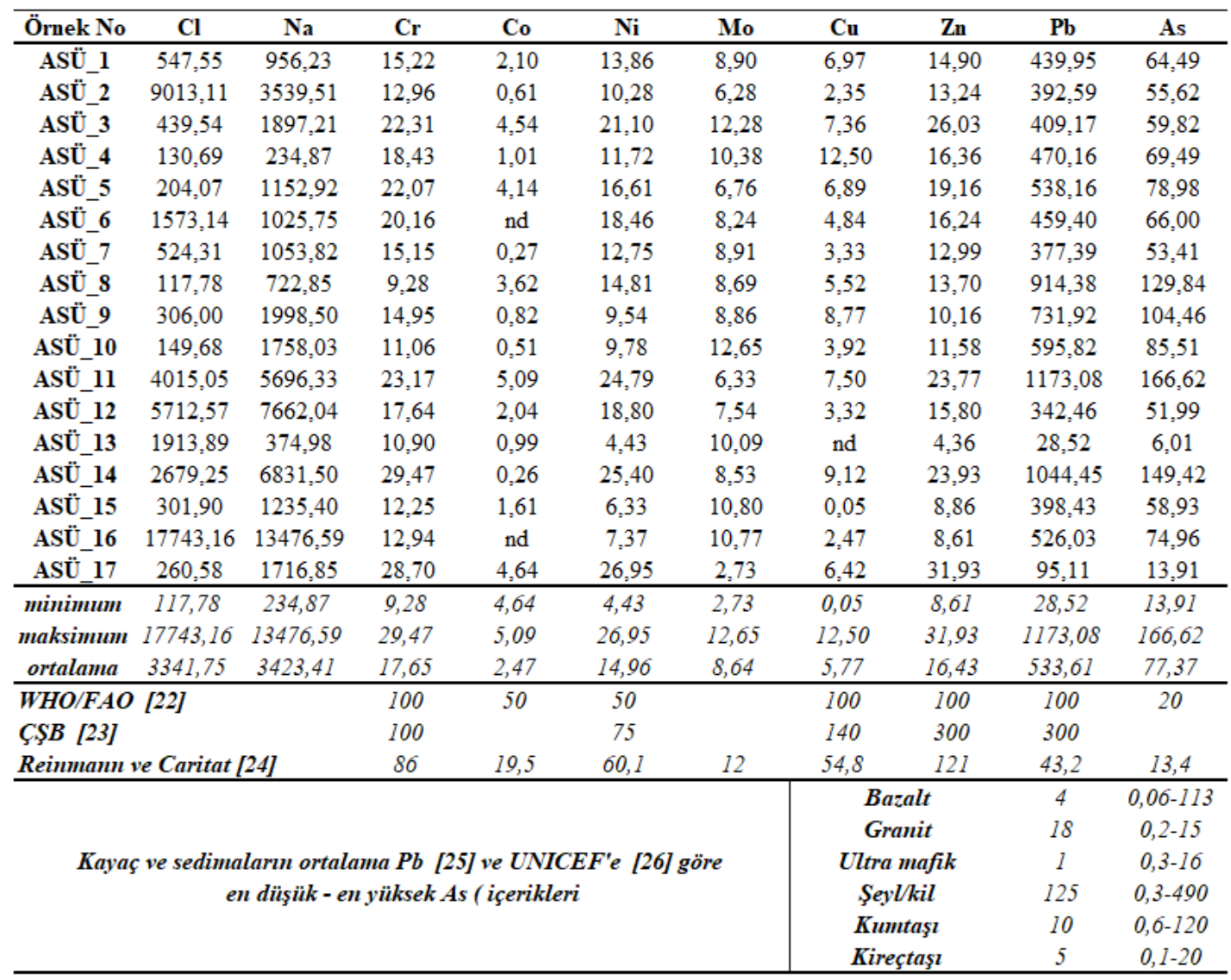




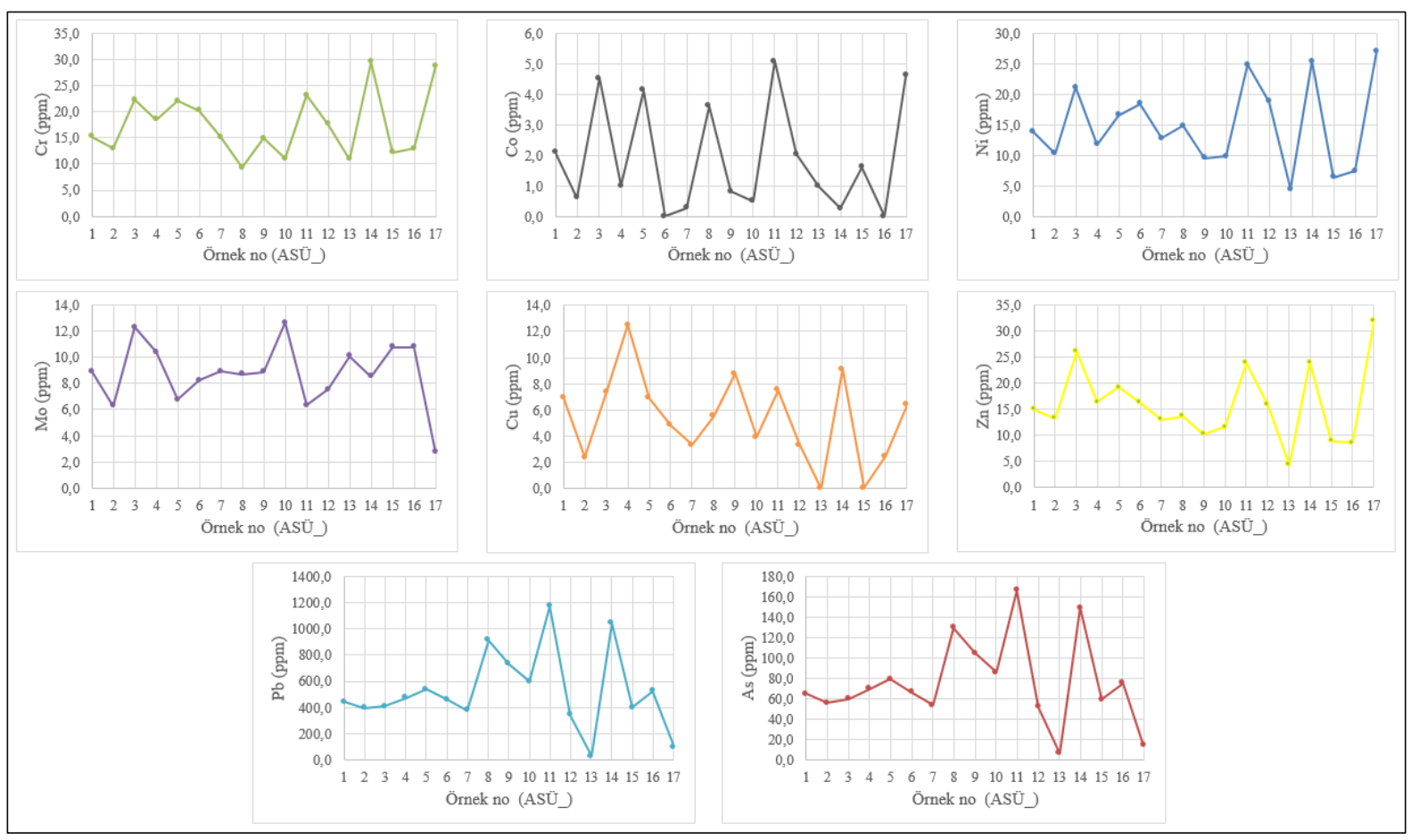

Şekil 6. Toprak numunelerinin iz element içeriklerinin örnekleme noktalarına göre dağılımları

Belirli sınırların üzerinde ağır metal kirliliğine maruz kalmış topraklarda yaşayan birçok bitki türü fizyolojik açıdan olumsuz yönde etkilenmektedir [27-28]. Böylesi topraklar üzerinde yetişen bitkilerin bünyelerinde birikip depolanan $\mathrm{Pb}$ besin zinciri/döngüsü sayesinde doğrudan ve dolaylı olarak diğer canlı türlerinin bünyelerine belirli miktarlarda girebilmektedir [29]. Gerek insan ve hayvan gerekse de bitki bünyesinden zor ve yavaş atılan $\mathrm{Pb}$, tüm canlılar için son derece zararlı toksik elementlerden biri olup WHO'ne göre ikinci grup kanserojen madde kabul edilmektedir [30]. Oldukça önemli çevresel kontaminantlardan olan $\mathrm{Pb}$ fazlalığı, çocuklarda IQ skorlarında düşüşe, davranış sorunlarına, işitme bozukluklarına ve agresifliğe [31], yetişkinlerde ise böbrek hasarı, hipertansiyon, kalp hastalığı ve doğurganlığın azalmasına yol açmaktadır [32-33]. Topraklarda bulunan $\mathrm{Pb}$ ve As zenginleşmeleri, antropojenik kaynaklardan (özellikle araç egsozlarından salınan petrol kökenli $\mathrm{Pb}$ veya madencilik faaliyetleri ile açığa çıkan $\mathrm{Pb}$ ve As) veya halihazırda kayaçlar içerisinde doğal olarak bulunan $\mathrm{Pb}$ ve As elementi ile zengin minerallerin çözünmesinden kaynaklanabilir. Kalkofil grubu elementlerden olan $\mathrm{Pb}$, doğada genellikle hipojen (galenit) ve süperjen (seruzit, anglezit) mineral formları şeklinde izlenir. Ortalama olarak granitlerde 18 ppm, bazaltlarda 4 ppm, ultramafik kayaçlarda 1 ppm, killi kayaç ve sedimanlarda 125 ppm, kumtaşlarında 10 ppm ve kireçtaşlarında 5 ppm Pb bulunur [25]. Pb'nun ekonomik olarak zenginleşmiş olduğu birincil alanlarda çoğu zaman $\mathrm{Cu}$ ve $\mathrm{Zn}$ ile bir arada bulunmasına rağmen yüzeysel ortam koşullarında birincil sülfürlü minerallerin bozunması ile $\mathrm{Pb}, \mathrm{S}$ ve $\mathrm{O}$ ile birleşerek $\mathrm{PbSO}_{4}$ (anglezit) bileşiminde ortamda kalırken, $\mathrm{Cu}$ ve $\mathrm{Zn}+2$ değerlikli iyonlar halinde çözeltiye geçip ortamdan 
kolaylıkla uzaklaşırlar. Bununla birlikte antropojenik Pb kaynağı olarak çalışma alanında en önemli unsur araç trafiğinin yoğun olduğu otoyollardır. Yapılan çalışmalar özellikle otoyolların hemen kenar noktalarından 500 m uzaklıklara kadar olan mesafelerde ve toprak örtünün 5-30 $\mathrm{cm}$ derinliklerine kadar $\mathrm{Pb}$ zenginleşmelerinin net olarak izlendiğini göstermektedir. [34-35]. Çalışma alanından toplanan örneklerin 500 metre sınırı gözetilerek daha uzak mesafelerden toplandığı (Şekil 1), örneklerin $40 \mathrm{~cm}$ toprak derinlikliği gözetilerek alındığı ve örnekleme noktalarındaki $\mathrm{Pb}$ zenginleşmelerinin otoyoldan uzaklaştıkça değişmediği (Şekil 6) düşünüldüğünde, çalışma alanı topraklarının $\mathrm{Pb}$ içeriklerinin antropojenik kökenli olmadığı söylenebilir.

Topraklarda bulunan As zenginleşmeleri de benzer şekilde antropojenik kaynaklardan (madencilik faaliyetleri, pestisit üretim tesisleri, yoğun tarımsal faaliyetlerden açığa çıkan As) veya halihazırda kayaçlar içerisinde doğal olarak bulunan As elementi içeren minerallerin çözünmesinden kaynaklanabilir. As'ce zengin hava ve içme suyu, toprak ve yiyecekler yolu ile insan bünyesine normal sınır değerler üzerinde alınabilir. As'nin uzun süre emilimi, midebağırsak, karaciğer, böbrek ve kalp hastalıklarının yanı sıra nörolojik, dermatolojik, hematopoietik, üreme ve kanser (dermis ve akciğer) semptom ve hastalıklara neden olmaktadır [7]. As'nin doğada doğal element formu dışında $\mathrm{Ni}, \mathrm{Co}, \mathrm{Fe}, \mathrm{Cu}$ ve S'lü farklı bileşiklere sahip birincil (nikolit, realgar, orpiment, kobaltit, arsenopirit, tenantit, enarjit) ile $\mathrm{Mn}, \mathrm{Mg}, \mathrm{Ca}, \mathrm{O}, \mathrm{OH}$ ve $\mathrm{H}_{2} \mathrm{O}$ 'lu bileşiklerden oluşan ikincil mineral (arsenolit, klodetit, anaberjit, eritrit, farmakosiderit) formları mevcuttur. Özellikle cevher içeren bölgelerdeki kayaçların cevherli zonları, bu zonlara yakın kayaç kesimleri ve yerinde oluşmuş toprak zonları As'ce normalden çok daha zengindir. Toprak örneklerinin As içerikleri, ortalama üst kabuk değerlerine göre (1,5 - 4,8 ppm; [36]) ve değişik bölgelerden toprakların As içeriğine göre (0,1 - 55 ppm; [37]) yükssek sayılabilecek değerlerdedir (Tablo 5). Ancak Aksaray bölgesinin bazı kesimlerindeki yeraltı sularının, bölge kayaçları ile ilişkili olarak, yüksek As içermesi (genellikle > 10 mg/l; [7]), bölgedeki kayaçların As değerlerinin görece yüksek olduğunun bir göstergesidir. Dolayısıyla Aksaray bölgesi bazı yeraltı sularının yüksek As içermesi ile bölgedeki toprak örneklerinin yüksek As içerikleri arasında bir ilişki olabilir. Oldukça toksik ve son derece zehirli bir element olan As kayaçlarda ve topraklarında kirliliğe sebep olabilmektedir. Hidrolojik çevrim sırasında su - kayaç etkileşimleri sonucunda As'ce zengin kayaçlardan çözünen As yüzey ve yeraltı sularına geçmekte ve böylece sularda As kirliliğine ve dolayısıyla da su kalitesinin bozulmasına neden olmaktadır. Ancak As'in mobilitesi ve toksitesi oksidasyon durumu ile belirlenebilmekte olup As ve bileşiklerinin su ve topraktaki davranışı, ortamın fizikokimyasal koşulları yanında 
biyotik ve abiyotik koşullarına bağlı olarak değişkenlik göstermektedir [38]. Bunun yanında topraktaki organik maddelerin oksidize olması ile ortaya çıkan As'nin diğer doğal bileşiklerine oranla, özelikle de +5 degerlikli bileşiklerinin toprakta daha fazla bulunduğu bilinmektedir [39]. Tüm bu bilgiler 1şı̆̆g altında, Şekil 6'dan da görüleceği üzere özellikle Pb ve As içeriklerinin grafikler üzerinde aynı desenleri göstermesi nedeniyle, bu elementlerin aynı kaynaklardan zenginleştiği sonucu çıkarılabilir. Dolayısıyla Kampüs alanından derlenen su numunelerinde As kirliliğine neden olacak bir bulguya rastlanamaması, topraklardaki As'nin su - kayaç etkileşimleri gibi süreçlerden ziyade topraklaşmanın hemen altındaki killerin ayrışmasından ve/veya topraklardaki organik maddelerin oksidasyonu sonucu ortaya çıkabileceğini veya toplanan su numunelerinin halihazırda güncel yağışlardan çok fazla etkilenen sular olabileceğini önermektedir. Tüm bu bilgilere rağmen, özellikle $\mathrm{Pb}$ ve As içeriklerinin antropojenik kaynaklardan gelip gelmediği ile ilgili daha ayrıntılı (bölgedeki volkanik kayaçların ve toprak örneklerinin daha detaylı örneklenmesi ve toprak örnekleme çalışmalarının A, B ve C seviyelerinden ayrı ayrı yapılması gibi) bir çalışmanın yapılması gerekmektedir.

Kampüs alanı içinde, doğal toprak örtüsünde potansiyel tuzlanmanın varlığının sorgulanması ve olası kökeninin araştırılması amacıyla toprak numunelerinde tuzluluğun en önemli göstergelerinden olan $\mathrm{Cl}$ ve $\mathrm{Na}$ içeriklerine bakılmıştır. $\mathrm{Cl}$ içerikleri 117,8 ile 17743,2 ppm arasında değişirken toprak numuneleri için ortalama $\mathrm{Cl}$ değeri 3341,7 ppm olarak ölçülmüştür. Numunelerdeki Na içerikleri ise 234,9 ile 13476,6 ppm arasında olup Na için ortalama değer 3423,4 ppm olarak tespit edilmiştir (Tablo 5). Cl ve Na değerlerine göre çizilen anomali dağılım haritalarında $\mathrm{Cl}$ ve $\mathrm{Na}$ değerlerinin alansal olarak birbirine uyumlu oldukları görülmektedir (Şekil 7).

$\mathrm{Cl}$ ve $\mathrm{Na}$ değerleri genel olarak Kampüs ve örnekleme alanının yaklaşık orta kesimlerinde yaklaşık KB-GD gidişli bir hat boyunca (Fen Edebiyat Fakültesi, Merkezi Laboratuvar ve Veteriner Fakültesi arasında kalan alan ile Merkezi Laboratuvarın KB's1 ve İlahiyat Fakültesi'nin yaklaş1k güneyi) görece düşük değerlere $(\mathrm{Cl}<10000$ ppm) sahipken, yerleşkenin güneybatı (BESYO civarı) ve doğu (Veteriner Fakültesi'nin güneydoğusu) kesimlerinde yüksek değerlere sahiptir ( $\mathrm{Cl}>10000$ ppm; $\mathrm{Na}>7500$ ppm). $\mathrm{Cl}$ ve Na değerleri, birbirlerinden farklı olarak, örnekleme alanının en kuzeybatısı) ve güneybatı ucunda, $\mathrm{Cl}$ içeriği Na içeriğine göre daha yüksek değerler gösterir (Cl> 10000 ppm; $\mathrm{Na}<7500$ ppm) (Şekil 7a ve 7b). Dağılım haritaları incelendiğinde $\mathrm{Cl}$ ve $\mathrm{Na}$ elementlerinin genel olarak benzer alanlarda uyumlu bir dağılım sergilemesi toprakta tuzlanmayı düşündürmektedir (Şekil 7). 

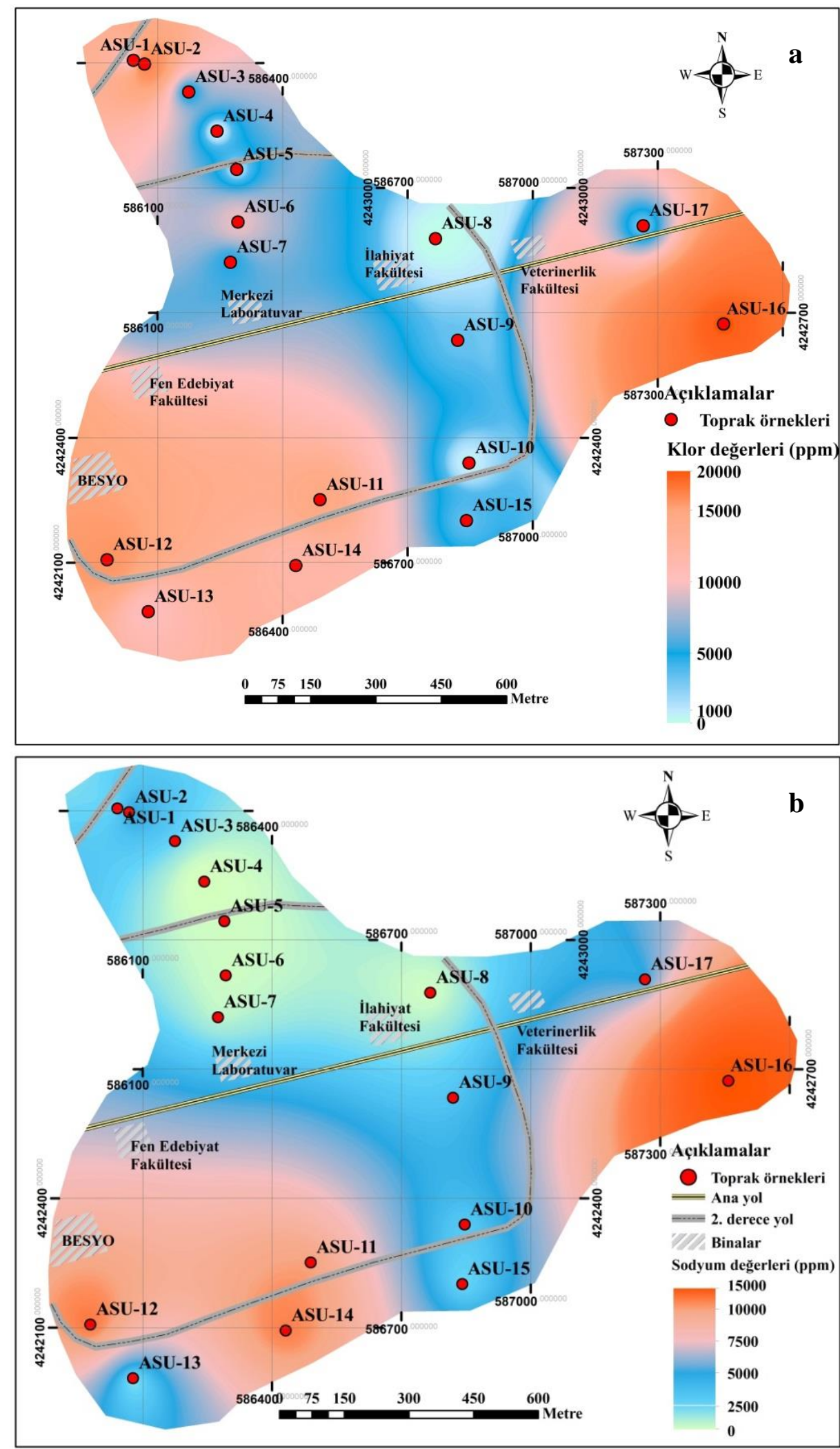

Şekil 7. Örneklerin a) $\mathrm{Cl}$ içeriğine göre ve b) Na içeriğine göre çizilen anomali dağılım haritaları

İnceleme alanındaki toprakların killi olması, hali hazırda toprak örneklerinin Na'ca zengin olmasını gerektirmektedir. Ancak bu durum topraklardaki Na'un kökeni açıklamak için tek başına yeterli gözüksede $\mathrm{Na}$ ve Cl'un benzer alanlarda bir arada uyumlu bir şekilde 
bulunuşunun kökensel olarak yeterince açıklanabilinmesini son derece kısıtlamaktadır. Bunun yanında kampüs alanına dikilen ağaçların yeterince gelişememesi ve çoğunun dikiminden belirli bir süre sonra kuruması topraktaki tuzluluğa işaret eden bir diğer önemli bulgudur. Kampüs'ün yaklaşık 2,5 km kuzeybatısı bulunan LindeGaz A.Ş.'ne ait kuyuların sı̆̆ kesimlerinde $\mathrm{CO}_{2}$ 'ce zengin jeotermal suların yaklaşık Na içeriği $9800 \mathrm{mg} / \mathrm{lt}, \mathrm{Cl}$ içeriği 17000 $\mathrm{mg} / \mathrm{lt}$, toplam tuzluluğu ise $28000 \mathrm{mg} / \mathrm{lt}$ ölçülmüş olup derine doğru toplam tuzluluk artmaktadır [40]. Bunun yanında çalışma kapsamında sulardan elde edilen $\mathrm{Cl}$ ve $\mathrm{Na}$ değerlerinin çok yüksek olmaması da dikkati çekmektedir. Ancak yüzey sularının çok daha hızlı toplanıp biriktiği dönemlerde veya karışım hızının jeolojik faktörlere bağlı olarak yavaş olduğu alanlardaki yüzeye yakın sığ kuyular ve kaynaklarda tuzluluk değerlerinin azalabileceği göz önüne alınmalıdır. Başka bir ifade ile tatlı su akiferlerinin tuzlanma potansiyeli ve görünür hızı, bölgenin jeolojik yapısı, hidrojeolojik sistem ve tektonizma ile kontrol edilmektedir [19]. Tuz Gölü'nün doğusundaki tatlısu akiferlerinde yapılan çalışmalarda tuzlu su kaynaklarından uzaklaştıkça suların toplam tuzlulukların azaldığı, tuzlu su girişiminin yayılım genişliğinin ise tuzlu su yoğunluğuna ve kotuna, yeraltı suyu kotuna ve litolojiye bağlı olarak değişkenlik gösterdiğini ortaya koymuştur [41]. Tüm veriler ışı̆̆ında, $\mathrm{Cl}$ ve Na'un bir kısmının kampüs alanı ve civarında yer alan derin $\mathrm{CO}_{2}$ 'ce zengin, tuzlu bir jeotermal akışkanın yüzeye doğru göçü sırasında belirli dönemlerde soğuk yeraltı suları ile kısmen de olsa karışabileceği, tuzlanan soğuk yeraltı sularının ise kayaç ve toprakla reaksiyonu sonucunda toprakların tuzlanmasına neden olabileceği ihtimali ortaya çıkmaktadır (Şekil 8). Böylesi bir durumun kesin olarak belirlenebilmesi kampüs alanında açılacak daha derin gözlem kuyularında yapılacak detaylı jeolojik, jeokimyasal ve hidrojekimyasal gözlem ve analizler ile mümkün olacaktır. Ayrıca bitkilerin kök, dal ve yapraklarından yapılacak sistematik biyojeokimyasal çalışmalar sorunun tüm yönleri ile ortaya konulmasına önemli katkı sağlayacaktır.

Kampüs alanında gözlenen ağaçlardaki gelişim sorunlarının bir diğer nedeni de olası antropojenik etkilerdir. Bu olası etkilerin en önemli olanları; dikim sırasında gerçekleşen hatalar, ağaçların gelişim sırasında yeterince sulanamaması ve bakımlarının düzenli yapılamamasidır. 


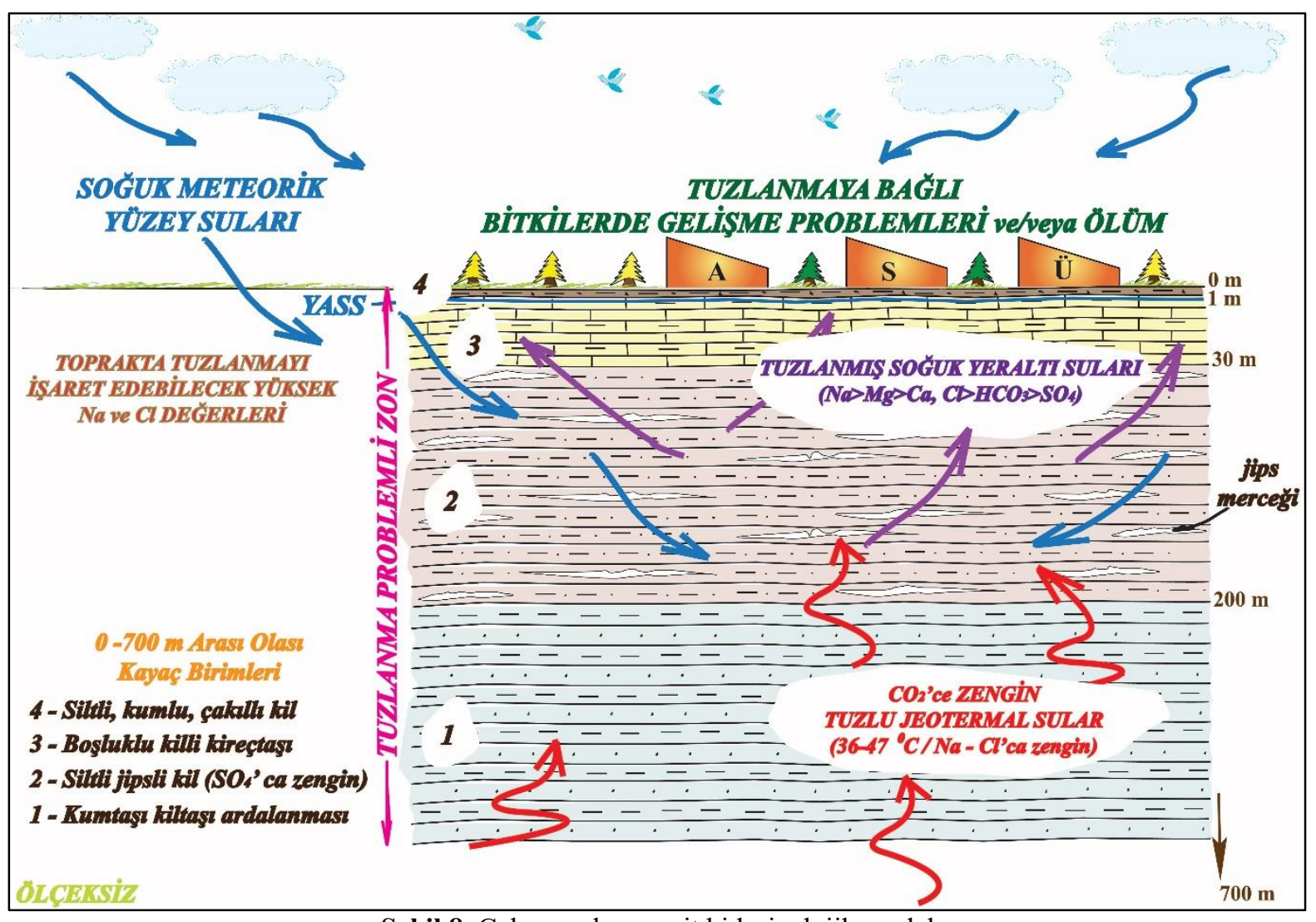

Şekil 8. Çalışma alanına ait hidrojeolojik model

\section{SONUÇLAR}

Bu çalışmada, Aksaray Üniversitesi kampüs alanının genel jeolojisi, sı̆̆ yeraltı sularının hidrojeokimyası, toprak jeokimyası ve zemin özellikleri ortaya konmuştur. Kampüs alanı, jeolojik olarak alttan üstte doğru sırasıyla 700 - 200 m arası kumtaşı-kil ardalanması, $200 \mathrm{~m}$ $30 \mathrm{~m}$ arasında siltli jipsli kil, 30 - $1 \mathrm{~m}$ arasında boşluklu killi kireçtaşı, $1 \mathrm{~m}-0 \mathrm{~m}$ arasında çoğunlukla siltli kum, az çakıllı kum ve siltli kil oluşan alüvyonlardan oluşmaktadır [16-17]. Hidrojeokimyasal analiz sonuçlarına göre, inceleme alanındaki suların iyon bolluk dizilimleri Aks-2 ve Aks-3 numaralı su örnekleri için $\mathrm{Ca}^{+2}>\left(\mathrm{Na}^{+}+\mathrm{K}^{+}\right)>\mathrm{Mg}^{+2} / \mathrm{Cl}^{-}>\mathrm{HCO}_{3}^{-}>\mathrm{SO}_{4}^{-2}$, Aks-1 ve Aks-4 su örnekleri için ise $\left(\mathrm{Na}^{+}+\mathrm{K}^{+}\right)>\mathrm{Mg}^{+2}>\mathrm{Ca}^{+2} / \mathrm{Cl}^{-}>\mathrm{HCO}_{3}^{-}>\mathrm{SO}_{4}^{-2}$ olarak belirlenmiştir. İnceleme alanı sularında $\mathrm{Cl}^{-}$iyonunun her iki su tipi için karakteristik olduğu görülmektedir. Su örneklerinin katyon sıralamalarındaki $\mathrm{Ca}^{+2}$ konsantrasyonunun artıp azalma ve TDS değerlerinde $\mathrm{Na}-\mathrm{Cl}$ su tipinde artma göstermektedir. Bu durum, suların mevsimsel gelişen yağışlardan etkilenmesini, yeraltındaki dolaşım sürelerinin uzamasını veya bu suların zengin sodyum içeren kayaçlarla teması sonucu iyon değişimin olduğunu göstermektedir. Dolayısı ile analizi yapılan bu sular karışım suları olarak ve sulama suyu standartlarına ve elektriksel iletkenlik değerlerine göre sulama suyu kalitesi düşük ancak kullanılabilir III. kalite 
sulama suyu olarak sınıflanmışlardır. Sondaj karotlarının laboratuvarda gerçekleştirilen deney sonuçlarına göre, toprak örtü altında gözlenen killi kireçtaşının düşük yoğunluğa sahip, orta poroziteli ve zayıf dayanımlı bir kayaçtır ve güvenli taşıma gücü $36,5 \mathrm{~kg} / \mathrm{cm}^{2}$ olarak hesaplanmıştır. İnceleme alanından toplanan 17 adet toprak numunesine göre elde edilen jeokimyasal bilgiler ve hazırlanan haritalara göre, topraklarda $\mathrm{Pb}$ ve As içerikleri kısmen yüksektir. $\mathrm{Pb}$ ve As elementinin kökeni olarak, elementel bolluklarının birbirleri ile uyumlu olması nedeniyle, bu elementlerin antropojenik etkilerden ziyade doğal jeolojik/hidrojeolojik süreçler ile ilişkili olduğunu göstermektedir. Hazırlanan haritalara göre kampüs alanının doğu, güney batı ve kuzey batı kesimlerinin $\mathrm{Na}$ ve $\mathrm{Cl}$ elementleri bakımından diğer bölgelere oranla daha yüksek değerler içermektedir. Bu alanlar, tarımsal faaliyetler yeşil alan çalışmaları ve saha yönetimi sırasında dikkate alınması gereken daha yüksek tuzlanma riski içeren alanlar olarak karşımıza çıkmaktadır.

\section{TEŞEKKÜR}

Bu çalışmaya maddi imkan sağlayarak destekleyen Aksaray Üniversitesi Rektörlüğü'ne, kaya mekaniği deneylerinin yorumlanmasına değerli fikir ve görüşleriyle katkı koyan Prof. Dr. Mehmet Sarı'ya, toprak numunelerinin derlenmesi sırasındaki yardımları için Dr. Murat Kalkan ve M. Haydar Terzi’ye, toprak numunelerinin analizleri için ASÜBTAM ve Dr. Bahattin Güllü'ye, su numunelerinin derlenmesi ve analizlerin gerçekleştirilmesi hususunda destekleri için ASÜ Çevre Mühendisliği Bölümü’ne teşekkür ederiz.

\section{KAYNAKLAR}

[1] H. Tuncay, Su Kalitesi, Ege Üniversitesi Ziraat Fakültesi, No: 512, (Akademik Yayın, İzmir, 1994) $243 \mathrm{~s}$.

[2] K. Haktanır, S. Arcak, Çevre Kirliliği, Ankara Üniversitesi Ziraat Fakültesi Toprak Bölümü, No: 1503, (Akademik Yayın, Ankara, 1998) 323s.

[3] N. Yıldız, Toprak Kirletici Bazi Ağır Metallerin ( $\mathrm{Zn}, \mathrm{Cu}, \mathrm{Cd}, \mathrm{Cr}, \mathrm{Pb}, \mathrm{Co}$ ve Ni) Belirlenmesinde Kullanılan Yöntemler, Atatürk Univ. Ziraat Fak. Derg. 32 (2) (2001) 207-213.

[4] Bozan, Balya (Balıkesir) Pb-Zn Yatağının Jeolojisi, Jeokimyası ve Izotop Karakteristikleri, YL Tezi, Aksaray Üniversitesi, Fen Bilimleri Enstitüsü (2017) 210s.

[5] S. Bozan, G. Demirela, İ. Kuscu, Balya (Balıkesir) Pb-Zn Yatağı'nin Jeolojisi ve Alterasyon Özellikleri, 70. Türkiye Jeoloji Kurultayı Bildiri Özleri, (2017) 496-497.

[6] H. Çelebi, G. Gök, Topraklarda Otoyol Ve Trafik Kaynaklı Ağır Metal Kirliliğinin Değerlendirilmesi, Pamukkale Üniv. Muh. Bilim. Derg., 24 (6) (2018) 1169-1178.

[7] L. Altaş, M. Iş̧1k, M.M. Kavurmacı, Determination of Arsenic Levels in the Water Resources of Aksaray Province, Turkey, Journal of Environmental Management 92 (2011) 2182-2192.

[8] M.F. Ertugay, M. Başlar, S. Sallan, Beyşehir-Isparta Karayolu Kenarinda Yetiştirilen Buğdaylarda Kurşun (Pb) ve Kadmiyum (Cd) Kirlilik Düzeylerinin Belirlenmesi, Dünya Gıda Dergisi, 1 (2012) 84-88. 
[9] M. Akyıldız, B. Karataş, Adana Şehir Merkezindeki Topraklarda Ağır Metal Kirliliğinin Araştırılması, Çukurova Üniversitesi Mühendislik Mimarlık Fakültesi Dergisi, 33 (2) (2018) 199214.

[10] M.C. Göncüoğlu, V. Toprak, İ. Kuşçu, A. Erler, E. Olgun, B. Rojay, 1992, Orta Anadolu Masifi'nin Bat1 Bölümünün Jeolojisi, Bölüm 2: Orta Kesim, TPAO Rap. No: 3155 (1992) 76s.

[11] M.C. Göncüoğlu, A. Erler, V. Toprak, E. Olgun, K. Yalınız, İ. Kuşcu, S. Köksal, K. Dirik, Orta Anadolu Masifi'nin Orta Bölümü'nün Jeolojisi, Bölüm 3: Orta Kızılırmak Tersiyer Baseni'nin Jeolojik Evrimi”, TPAO Rap. No. 3313 (1993) 104s.

[12] M.C. Göncüoğlu, K. Dirik, A. Erler, K. Yalınız, L. Özgül, İ. Çemen, Tuzgölü Havzası Batı Kısmının Temel Jeolojik Sorunları”, TPAO Rapor No: 3753 (1996).

[13] Y. Arıkan, The geology and Petroleum Prospects of the Tuz Gölü Basin, Bulletin of the Mineral Research and Exploration Institute of Turkey, 85 (1975) 17-44.

[14] K. Dirik, O. Erol, Tuzgölü ve Civarının Tektonomorfolojik Evrimi, Orta Anadolu, Türkiye, Haymana-Tuzgölü-Ulukışla Basenleri Uygulamalı Çalışma (Workshop), TPJD Özel Sayı: 5 (2000) $27-46$.

[15] İ. Çemen, M.C. Göncüoğlu, K. Dirik, Structural Evolution of the Tuz Gölü Basin in Central Anatolia, Turkey, The Journal of Geology, 107 (6) (1999) 693-706.

[16] O. Usta, Aksaray'da Doğal Karbondioksit $\left(\mathrm{CO}_{2}\right)$ Üretimi, Su-Enerji-Sağlık Sempozyumu Bildiri Özleri, 20-23 Ekim (2008) 64, Aksaray.

[17] M.M. Kavurmac1, M. Sarı, G. İnce, Aksaray Üniversitesi Kampüs Alanının Jeoteknik Değerlendirlmesi, Aksaray Üniversitesi Müh. Fak., (2008), Aksaray.

[18] C. Güler, G.D. Thyne, Hydrologic and Geologic Factors Controlling Surface and Groundwater Chemistry in Indian Wells - Owens Valley Area, Southeastern California, USA. Journal of Hydrology, 285 (2004) 177-198.

[19] M.M. Kavurmacı, H. Elhatip, Tuzlu Göl Sistemlerinde Tuzlusu-Tatlısu Arayüzey İlişkilerinin İncelenmesi; Tuz Gölü Örneği, 68. Türkiye Jeoloji Kurultayı Bildiri Özleri Kitabı, 06-10 Nisan (2015) 190-191 Ankara.

[20] International Soil And Rock Mechanics ISRM Rock Characterization, Testing and Monitoring, ISRM Suggested Methods, Brown ET (editor), (Pergamon Press, Oxford, 1981) 211p.

[21] S. Yıldırım, Zemin İncelemesi ve Temel Tasarımı, (Birsen Yayınları, İstanbul, 2002).

[22] T. M. Chiroma, R. O. Ebewele, F.K. Hymore, Comparative Assessement of Heavy Metal Levels in Soil, Vegetables and Urban Grey Waste Water used for Irrigation in Yola and Kano, International Refereed Journal of Engineering and Science, 3 (2) (2014) 01-09.

[23] Çevre ve Şehircilik Bakanlığı, Toprak Kirliliği Kontrolü Yönetmeliği, 2001.

[24] C. Reimann, P. Caritat, Chemical Elements in the Environment, (Springer-Verlag, Berlin, 1998) pp.397.

[25] A. Gökçe, Maden Yatakları, (Cumhuriyet Üniversitesi Yayınları, Sivas, 2000), 335s.

[26] UNICEF, United Nations Children's Fund, Arsenic Primer, Guidance for UNICEF Country Offices on The Investigation and Mitigation of Arsenic Contamination, Water, Environment and Sanitation Section Programme Division, (Unicef, New York, 2008)

[27] K.F. Zengin, Ö. Munzuroğlu, Fasulye Fidelerinin (Phaseolus vulgaris L.) Kök, Gövde ve Yaprak Büyümesi Üzerine Kadmiyum $(\mathrm{Cd}++)$ ve Civa $(\mathrm{Hg}++)$ 'nın Etkileri, Cumhuriyet Üniversitesi FenEdebiyat Fakültesi, Fen Bilimleri Dergisi 24 (1) (2003) 64-75.

[28] F.N. Kafadar, S. Saygıdeğer, Gaziantep İlinde Organize Sanayi Bölgesi Atık Suları İle Sulanan Bazı Tarım Bitkilerinde Kurşun (Pb) Miktarlarının Belirlenmesi, Ekoloji 19 (75) (2010) 41-48. 
[29] A. Sales, A. Alvarez, M.R. Areal, L. Maldonado, P. Marchisio, M. Rodrfgueza and E. Bedascar, The Effect of Different Propolis Harvest Methods on Its Lead Contents Determined by ETAAS and UV-Vis, S. Journal of Hazardous Materials, 137 (2006) 1352-1356.

[30] G. Özkan, Endüstriyel Bölge Komsuluğunda Kıyısal Kırsal Alandaki Hava Kalitesi Muallimköy’de Partikül Maddede ve Topraktaki Ağır Metal Kirliliği, YL Tezi, Gebze YTE, (2009) 64s.

[31] P. Grandjean, P.J. Landrigan, Neurobehavioural Effects of Developmental Toxicity", The Lancet Neurology, 13 (2014) 330-338.

[32] H. Hu, R. Shih, S. Rothenberg, B.S. Schwartz, The Epidemiology of Lead Toxicity in Adults: Measuring Dose and Consideration of Other Methodologic Issues, Environmental Health Perspectives, 115 (2007) 455-62.

[33] A. Mathee, T. Kootbodien, T. Kapwata, N. Naicker, Concentrations of Arsenic and Lead in Residential Garden Soil From Four Johannesburg Neighbourhoods, Environmental Research, 167 (2018) 524-527.

[34] N. Teutsch, Y. Erel, L. Halicz, A. Banin, Distribution of Natural and Anthropogenic Lead in Mediterranean Soils, Geochim. Cosmochim Acta, 65 (2001) 2853-2864.

[35] L. Mao, E.H. Bailey, J. Chester, J. Dean, E.L. Ander, S.R. Chenery, S.D. Young, Lability of Pb in Soil: Effects of Soil Properties and Contaminant Source, Environmental Chemistry, 11 (2014) 690701.

[36] R.L. Rudnick, S. Gao, The Composition of the Continental Crust, In: Holland, H.D. and Turekian, K.K., Eds., Treatise on Geochemistry, Vol. 3, The Crust, (Elsevier-Pergamon, Oxford, 2003) 1-64.

[37] R.W. Boyle, R. Jonasson, The Geochemistry of Arsenic and Its Use As An Indicator Element In Geochemical Prospecting, Journal of Geochemical Exploration, 2 (3) (1973) 251-296.

[38] D.Q. Hung, O. Nekrassova, R.G. Compton, Analytical Methods for Inorganic Arsenic In Water: A Review, Talanta, 64 (2004) 269-277.

[39] C. Karadaş, Balya İlçesi ve Yakın Köylerindeki Toprak Kirliliğinin Çocuklar Üzerine Etkisinin In Vitro Gastroinstestinal Ekstraksiyon Yöntemi ile Belirlenmesi, Yüksek Lisans Tezi, Balıkesir Üniversitesi (2008) 129s.

[40] M. Afş̧in, S. Bayarı, Ü.G. Durukan, O. Usta, Kapalı Havzası Yeraltısuyundaki Karbondioksitin Kökeni, 1. Ulusal Su Kaynakları Yönetimi Sempozyumu, Karaman Üni., 20-22 Ekim (2010), Karaman.

[41] M.M. Kavurmacı, Şereflikoçhisar Havzası Yeraltı Sularının Hidrojeolojik ve Hidrokimyasal Açıdan İncelenmesi ve Bölgedeki Tuzlusu Girişiminin Çevresel Etkilerinin Araştırılması, Doktora Tezi, Aksaray Üniversitesi, Fen Bilimleri Enstitüsü (2013) 210s. 